\title{
The Morphology and Development of the Ascocarp in Monascus.
}

\author{
BY
}

\author{
B. T. P. BARKER, M.A., \\ Gonville and Caius College, Cambridge. \\ With Plates XII and XIII.
}

SOURCE.

T

$\mathrm{HE}$ fungus which forms the subject of this paper was obtained from a small cake of material which is used in the preparation of an Eastern Asiatic spirit, 'Samsu.' The cake was supplied to me by the kindness of Mr. D. T. GwynneVaughan and Mr. R. H. Yapp, the former of whom collected it during the Skeat Expedition to the Malay Peninsula.

A small portion of the cake was added to a flask of sterilized rice, kept at $25^{\circ} \mathrm{C}$., and an abundant mycelial growth was quickly formed. This consisted of a mixture of several Fungi, which were separated by the method of fractional plate cultures. Among them was the species here described.

It is easily grown in pure cultures on various nutrient media, especially at a temperature of $25-30^{\circ} \mathrm{C}$. Growth below $20^{\circ} \mathrm{C}$. is very slow. In these cultures a vigorous mycelium is quickly produced, which soon bears numerous conidia in chains. Later the mycelium becomes vividly pigmented with a pigment, from a reddish orange to a purple tinge. Ascocarps are then formed abundantly, and all stages in their development can easily be obtained.

[Annals of Botany, Vol. XVII. No. LXV. January, 1903.] 


\section{METHODS.}

The methods used for determining the development and structure of the ascocarp in this fungus were twofold, viz. (a) The direct observation of the developing fructification under a Zeiss $\frac{1}{12}$ oil immersion lens (eye pieces 4 and 8 ) in hanging drop cultures. The hanging drops were made of beer-wort agar (beer-wort $9^{8}$ per cent., agar 2 per cent.), and were infected with conidia from pure cultures of the fungus. The temperature was kept constant at $27^{\circ} \mathrm{C}$., this degree being much more suitable for the rapid development of the ascocarps than the ordinary room temperature, growth practically ceasing under $\mathrm{I} 8^{\circ} \mathrm{C}$.

The results of these observations were checked by the examination of living material, containing developing ascocarps in all stages, under similar powers of magnification. In this manner the results of observations of comparatively few ascocarps, the growth of which had been watched from the start to the formation of the ripe spores, were generalized.

(b) The examination of material after killing and staining. The fixing fluid used was the weak Flemming mixture. Ascocarps of various ages were not only examined whole, but also in series of sections, cut by the microtome. The material for these two methods was obtained by different means.

For the examination of the entire ascocarps cultures of the fungus in a pure condition were made by infecting a tube of beer-wort with conidia, pouring the infected wort into a sterile Petri dish until the liquid covered the bottom of the dish to a depth of one-eighth to one-quarter of an inch, and then allowing growth to take place at a temperature of $25^{-2} 7^{\circ} \mathrm{C}$. The first stages of the ascocarps made their appearance after forty-eight hours; and at the end of three and four days material was picked out with a sterile platinum needle and fixed. Such material contained ascocarps in all stages. After fixation, it was washed for twenty-four hours in running water and then hardened in a series of alcohols; the blackening produced by the osmic acid of the fixing fluid was 
removed by treatment with hydrogen peroxide; and it was then stained with safranin for twenty-four hours. After dehydration with absolute alcohol, the stained material was placed in xylol for a few minutes until perfectly transparent, then teased out carefully and mounted in xylol-balsam.

The reason for cultivating the fungus in a thin layer of liquid in a Petri dish was that, when it was grown in any considerable depth of liquid, growth took place more slowly and ascocarps were produced more irregularly and less generally.

The material used for section cutting was obtained from plate-cultures on beer-wort agar. Such cultures showed the preliminary stages of fructifications after forty-eight to seventy-two hours from infection with conidia at $25^{-2} 7^{\circ} \mathrm{C}$. At intervals of twelve hours portions of the agar, containing the fungus were fixed, washed, and hardened as above. After passing successively through half-alcohol and half-xylol, pure xylol, and xylol-paraffin into paraffin, series of sections were cut by microtome. These were treated in the usual manner, decolorized by hydrogen peroxide and stained by the Flemming triple stain. In a few cases the iron-alum haematoxylin stain was used, but apart from bringing out the conspicuous nucleoli it was unsatisfactory. The cultures on beer-wort agar have a considerable advantage over those in liquid media, in that the formation of ascocarps is general and plentiful throughout, and at the same time at any given moment the majority of them are at approximately the same stage of development. Control is therefore easy. They are, however, unsuited to the previous method of examination, since satisfactory teasing of the agar material is impossible, the agar itself at the same time partially obscuring the fungus.

\section{The Development of the Ascocarp.}

The results obtained from the examination of living material will first be considered.

In-a hanging drop-culture of beer-wort agar, infected with 


\section{70 Barker.-The Morphology and Development of}

conidia and kept at $27^{\circ} \mathrm{C}$, germination soon takes place by the putting out of one or more germ-tubes by a conidium, which at the same time increases slightly in size. The germ-tubes grow rapidly, transverse septa soon appear, and numerous branches are produced (see Fig. I). In this way a vigorous and abundant mycelium is quickly formed. While the system of branching apparently does not follow any definite rule, it nevertheless often happens that the formation of a branch from one side of a hypha is responded to by the formation of another on the opposite side of the hypha, so that an arrangement of the branches in pairs is met with (see Fig. I,e). Another point to be noticed is that there is a considerable tendency on the part of the hyphae to swell at various points (see Fig. I, $e$ ). In a few cases the hanging drop almost dried up at the time of germination. In such instances the germinating conidia and hyphae swelled enormously, the subsequent branches only regaining the normal size when the drop again became more moist.

After about twenty-four hours, the time, however, depending apparently principally upon the amount of mycelium present in proportion to the size of the drop, conidia begin to be formed. These are produced by the swelling of the tips of hyphae into spherical or ovoid bodies, which are then cut off by transverse septa. Chains of these conidia are usually produced by the swelling of the hypha immediately under the terminal conidium, the swollen part being then cut off by a transverse septum to form a second conidium, and the same process being then repeated time after time immediately below the conidium last formed. Such chains may be found, composed of as many as eight to ten conidia, although usually the number is considerably less.

The conidia are developed very rapidly at first, but the rate of formation gradually becomes slower until very few fresh ones are formed. It is at about this time that the development of the ascocarps begins, being about twenty-four hours after the formation of the first conidia.

The older hyphae are then filled with large vacuoles, and 
contain many large fatty-looking globules and granules. The side branches, however, are in many cases filled with dense, semi-transparent protoplasm. In certain of these a small terminal cell is cut off by the formation of a transverse septum a little distance below the tip (Fig. 2, a). Immediately below the septum a small lateral protuberance makes its appearance (see Fig. 2, $b$ ), the development of which causes the terminal cell to become bent at a slight angle from the direction of growth of the rest of the hypha. This protuberance then becomes the main growing point of the hypha, and no further growth takes place in the direction of the previous growth, but the developing hypha instead becomes closely applied to the stationary terminal cell and following its course, at the same time pushing it more and more from its original position, until eventually it assumes a direction more or less at right angles to the parent hypha (see Fig. 2, $c, d, e$ ). The terminal cell usually grows but little after its formation, but in some cases a more considerable increase in length, and even branching and conidial formation, occur (see Fig. $3, a$ and $b$ ).

Occasionally a similar process occurs at a considerable distance from the tip of a hypha, the new growing point developing immediately beneath a transverse septum and proceeding, as in the previous case, to bend the apical portion of the hypha from its original course (see Fig. 4); on some occasions also immediately beneath a conidium (see Fig. 6), or beneath the lowest member of a chain of conidia (see Fig. 7).

In both instances the subsequent development of the new growing point is similar. As already stated, it grows into a small hypha closely applied to the apical portion of the original hypha. Its course along this is usually almost strictly parallel with it but slightly curling round it, but in some cases a very pronounced spiral winding occurs, to the extent at times of more than one complete revolution (see Fig. 5). The growth in length of this hypha is limited, rarely exceeding $40 \mu$. By the time that the limit of its growth in length has been reached, a septum has been formed in the neighbourhood of its point of origin (see 


\section{I72 Barker.-The Morphology and Development of}

Fig. 2,e). The formation of the septum at this point marks off a single cell, composed of the whole of the small hypha developed as the result of the growth of the small protuberance or new growing point mentioned above. This cell, for reasons given later, will be henceforward termed the ascogonium, while the original terminal cell of the parent hypha, clasped by the ascogonium, will be described as the antheridial branch. In those instances in which the ascogonium has been produced at some distance from the apex of the parent hypha, that portion, the direction of which has been deflected by the growth of the ascogonium, will be regarded as the antheridial branch.

There have now been formed two organs, the ascogonium and the antheridial branch, the subsequent behaviour of which leads to the production of the ascocarp. They must therefore be regarded as the archicarp. Both of them at this period are filled with dense semi-transparent protoplasm, devoid of vacuoles but containing a few bright granules.

The next step in the development of the ascocarp consists in a fusion between the two organs. The fusion takes place in most cases at the tip of the ascogonium, between that portion of it and the part of the antheridial branch in its immediate neighbourhood (see Fig. $2, f$ ). Occasionally, however, fusion takes place a little distance below the tip of the ascogonium (see Fig. 8). The fusion appears to take place in the following manner. A small papiliar outgrowth is developed on the antheridial branch at the point, where fusion eventually takes place, between that organ and the closely applied ascogonium. Solution of the walls then occurs at the point of contact between the papilla and the ascogonium, the protoplasm of the two organs becoming continuous. There are two reasons for supposing the fusion to take place in this manner. Firstly, when the fused portion has become more conspicuous, the antheridial branch at the place of fusion is slightly swollen on the side in contact with the ascogonium and apparently projects into it. That is to say, it is the wall of the antheridium that constitutes the wall of the communi- 
cating canal between the two hyphae (see Fig. 9). Secondly, in certain cases no fusion takes place and no ascocarp is developed; but, nevertheless, a small papilla is developed on the antheridial branch between it and the closely applied ascogonium, or, in some cases, where the ascogonium only partially develops, at the place where the tip of the ascogonium would normally be (see Fig. Io).

The exact moment of fusion is very difficult to determine in most cases, since the close contact between the two organs and their optical properties are such as to obscure almost completely the details of the process. I have never observed, either in the living state or in the fixed and stained material, a case of which it could be stated positively that fusion had occurred before the formation of the septum cutting off the ascogonium. I have, however, seen instances of undoubted fusion after the formation of the septum but before the occurrence of the next stage about to be described. It seems probable, therefore, that fusion succeeds the cutting off of the ascogonium, and is preliminary to and also necessary for the development of the subsequent stages. With regard to the necessity for fusion, I have never seen a developing ascocarp, in which the archicarp was still visible, that did not show perfectly clearly the existence of a fusion between the antheridial branch and the ascogonium.

It should be mentioned here also that, while the fusion is practically invisible under a one-sixth inch objective and often under a one-twelfth inch oil immersion objective in the early stages of the developing ascocarp, it becomes easily visible later, when swelling and the degeneration of the contents of the antheridial branch and of the tip of the ascogonium occur.

Positive proof of the existence of a fusion at quite an early stage is forthcoming, however, since I have seen granules pass from the ascogonium into the antheridial branch, and vice versa, in specimens in the stage now about to be described.

This stage consists in the cutting off of a cell in the ascogonium by the formation of a septum across that organ between the place of fusion and the septum at its base 


\section{I74 Barker. - The Morphology and Development of}

(see Fig. $2, g$ ). The penultimate cell thus cut off varies considerably in size at the time of formation (see Figs. $2, g ; 3, b$; and 5), but in all cases it has dense semi-transparent slightly granular protoplasmic contents and practically no vacuoles.

It is from this penultimate cell that the 'sporangium' of previous authors is developed.

On account of its importance and position I propose to term it the 'central cell,' the older terms 'sporangium' and 'ascus' being, as will be seen later, erroneous.

It soon begins to swell up, and vacuoles make their appearance, its shape during the earlier period of swelling being more or less reniform or bean-shaped (see Fig. 2, $h$ ). Later it becomes spheroid or ovoid.

The ascogonium consists during this period of two cells, viz. the central cell and a cell at its apex, which is made up of that portion of the organ which has taken part in the fusion with the antheridial branch, and is more or less comparable to a 'trichogyne' (see Fig. 2, $g$, \&c.). Shortly after the formation of the central cell, investing hyphae begin to be formed around it. These are developed from the hypha which has produced the archicarp, and arise from that part of it immediately below the limiting septum of the ascogonium, i.e. just below the central cell.

In most cases a single hypha is produced in that region; and this proceeds to grow up around the central cell, closely applied to it (see Fig. I I, a). It begins very quickly to put out lateral branches, which also clasp the central cell. The lateral branches, especially the earlier ones, are usually produced in pairs, and grow in opposite directions. These, in their turn, produce other branches, also clasping the central cell ; and development in this manner continues until the central cell is covered on every side, except those in contact with the antheridial branch and 'trichogyne cell,' by investing hyphae. The growth of these hyphae then ceases (see Fig. I I, $b-d$ ).

In speaking of the central cell as being invested on every side by these hyphae, it must not be understood that the whole surface is completely covered by them. What is 
meant is that there is no large continuous surface left uncovered and unclasped, on every side by investing hyphae. But here and there the clasping hyphae leave exposed small portions of the surface of the central cell, and in this sense the investment is incomplete. Nevertheless, the whole of the central cell is clasped by the hyphae (see Figs. II, $d$; and 12).

In some cases the main investing hypha does not itself become closely applied to the central cell, this function being left to some of its branches and their succeeding branches (see Fig. 12). In other cases, after growing closely applied to the cell for part of its course, it continues to grow for some distance beyond it (see Fig. II, $a$ ). Occasionally also some of its branches do not become closely applied to the central cell (see Fig. 12).

In those cases which have been described up to the present, all the investing hyphae have originated from a single outgrowth from the main hypha, just beneath the ascogonium. Occasionally, however, the investment of the central cell is completed by the growth of one or more other hyphae from the same region (see Fig. I2). The development of investing hyphae is often followed by the development of small branched hyphae on other parts of the hypha bearing the ascocarp. They are sometimes irregularly branched, but often the branches are produced in pairs and grow in a curved manner, as if clasping a spherical body. Fig. 14 shows examples of both kinds. The details of the development of the investing hyphae are seen fairly easily in the earlier stages under an immersion lens, but with lower powers of magnification they can be but imperfectly traced. In the later stages, even with the use of high powers of magnification, it becomes very difficult to observe with certainty what is happening.

The hyphae are at first very small, compared with the ordinary hyphae of the fungus and with the archicarp. Their protoplasm is very dense and less transparent than that of the central cell. Consequently the course of development 
of the earlier branches is easily traced. Later, however, the hyphae begin to swell, and become more transparent, and, after further growth in length and branching have ceased, the individual hyphae are very indistinctly seen, and the system could not be correctly figured if the development from a very early stage were not followed. Further swelling and, at the same time, flattening out render them, except in a few cases here and there, almost invisible. A large number of oil drops also appear, gradually increasing in size. Later still, after the protoplasmic contents seem to have entirely degenerated and to have disappeared, they appear as nothing more than flattened walls (see Fig. I3, $a-c$ ).

At this stage the fructification has acquired a brownish colour, due no doubt to these degenerated hyphae.

While all these changes have been taking place, important developments of the central cell have occurred. These can be seen but indistinctly owing to the obscuring effect of the investing hyphae, particularly about the period of swelling up and flattening of those structures. At the time of the formation of the first investing hypha, the central cell is comparatively small, although as has been stated above, swelling has already begun to occur. The swelling continues during the formation of the hyphae, to such an extent that the whole fructification becomes a conspicuous and comparatively large body. By this time the contents of the antheridial branch and the 'trichogyne cell' have become disorganized and eventually disappear. At the same time those two structures have swollen considerably, and the fusion between them is then very easily seen. Later, their walls collapse, and in most cases all traces of their existence are lost (see Fig. I $3, a, b, c)$.

When the growth of the investing hyphae has ceased the central cell can still be seen, although with difficulty. Its outlines are no longer sharply marked; but here and there portions of its surface can be sharply focussed, where the absence of investing hyphae has left it exposed. Later, when the hyphae begin to swell and become flattened out, such 
parts of the surface are seen to bulge slightly, as though there were considerable pressure being exerted inside, which forced an expansion at the unclasped points. In a few cases I have seen a comparatively conspicuous bulging at one point of the ascocarp. This may be an important fact, and will be referred to later as possibly representing the formation of the first ascogenous hypha (see Fig. II, a).

After this stage the optical effects produced by the swollen central cell and the swelling and flattening investing hyphae, together with the innumerable oil drops, render further details invisible for some considerable period in the development of the ascocarp.

The general impressions produced up to the stage when the contents of the interior of the fructification again become visible are as follows:-

At some part of the interior a small spherical space becomes visible. This is clearly defined on account of its optical properties differing from those of the rest of the ascocarp. The position of this space is not necessarily the same in all cases. Sometimes it appears towards one side of the ascocarp and sometimes apparently in the centre (see Fig. I3, $a$ ). It increases in size until it fills almost the whole of the interior of the fructification. As it increases in size it loses its apparent homogenous appearance; and soon, when comparatively large, presents the appearance of being filled with numerous large vacuoles. This apparent structure remains until the contents of the ascocarp become more clearly visible (see Fig. I $3, b$ ).

As the contents gradually become more clearly visible, the misty appearance which has hitherto obscured the development is slowly lost, and it becomes possible to distinguish by degrees a mass of branching hyphae in the centre of the ascocarp, occupying the previous vacuolated space. It is undoubtedly to these hyphae that the appearance of ' vacuolation' was due.

The courses of the hyphae cannot be traced, since the 


\section{I78 Barker.-The Morphology and Development of}

interior is filled with such a tangled mass of hyphae and structureless material that the lower ones are obscured.

Some of the hyphae are much larger than others, and are much vacuolated. Others are of varying sizes, but filled with dense protoplasm. Soon it can be seen that some of the latter have become spherical in shape, and in these, after a short time, spores are formed, eight spores in each (see Fig. $\mathrm{I}_{3}, c$ ).

There can be no doubt that these spore-containing hyphal branches are in reality asci.

The other hyphae and also the walls of the asci soon disintegrate and the spores are set free in the interior of the fructification, mixed with a mass of débris.

In this way the mature ascocarp is formed. It appears to be nothing more than a spherical body, consisting of a structureless brown wall enclosing a mass of spores mixed with mucilaginous substance. It might certainly be mistaken for a sporangium.

The spores are liberated from this structure by the breaking down of the wall.

The ripe spores are very characteristic in appearance. They have a reddish-brown colour, a bright yet almost opaque look, and in shape are ovoid with pointed ends. Their size is about $8 \mu$ by $4 \mu$.

This account of the development of the ascocarp derived from the study of living material is supplemented by observation of fixed and stained material, an account of which will now be given.

Owing to the comparatively small size of the mature ascocarps and the transparency of all stages after mounting whole in canada balsam, very few additional details have been gained by the study of series of sections beyond those obtained by the observation of uncut, stained, and teased material; so that the results of the two methods may well be considered together. The series of sections of the various stages have an advantage over the teased material in that the nuclei are much more conspicuous, and the branching of the 
hyphae from which the asci are eventually developed may be to some extent traced; but they have considerable disadvantages. Not only is there some difficulty in finding all the members of a series of sections of an ascocarp and of piecing them together accurately, but also in the cutting of the series the sections of the ascocarp become crushed or partially folded up, and in the subsequent floating out of the sections in hot water complete unfolding often does not take place; in particular great difficulty is experienced in distinguishing between certain portions of the central cell and the investing hyphae.

Starting with the formation of the ascocarp, the chief interest in the stained material is fixed on the behaviour of the nuclei. On the whole the iron-alum haematoxylin method of staining is the most satisfactory for the nuclear work.

The cells of the mycelium are multinucleate, and the same appears to be the case with the conidia from the time of their formation. The growing points of the hyphae, particularly those of the archicarp-bearing hyphae, are crowded with nuclei. The nuclei appear to stain in two ways. In the young hyphae and the archicarps the nuclei are distinguishable separately only by their nucleoli, which stain very deeply and are relatively large, the bodies of such nuclei being apparently almost unstained, each thus appearing as a light spherical space containing a deeply stained granule. The protoplasm stains rather deeply in these portions of the mycelium, not so deeply as the nucleoli, but darker than the bodies of the nuclei, this doubtless being due to the presence of some substance peculiar to the protoplasm of young hyphae which has a strong affinity for stains. On this account, and owing also to the large number of nuclei present in these parts, it is almost impossible to define the limits of any particular nucleus. Their numbers are indicated by the number of nucleoli. In the older hyphae the bodies of the nuclei stain rather deeply and almost uniformly, but no nucleolus is conspicuous, and the protoplasm with haematoxylin is almost unstained. 
They are thus clearly defined. In certain parts, particularly in the antheridial branches after fusion with the ascogonia, an intermediate method of staining is found. The bodies of the nuclei stain uniformly but not deeply, while a distinct network of more deeply stained material is visible and an inconspicuous nucleolus is usually seen.

In both the antheridial branch and the young ascogonium there are numerous nuclei. At the time of fusion several may be found in both organs close to the place where fusion occurs, especially in the antheridial branch (Fig. I 5 a). After fusion no doubt a migration of nuclei occurs from the latter into the ascogonium. At this time the canal between the two organs is practically indistinguishable, and it is impossible to determine clearly if nuclei are situated in it.

The occurrence of several nuclei in its neighbourhood is, however, significant; and in many cases nuclei appear to occupy the passage (Fig. I 5, a). At a slightly later stage, when the canal is more easily seen and the central cell has been cut off by the formation of a wall, a nucleus can occasionally be found in the passage (see Fig. $15, b$ ).

The ascogonium, after fusion with the antheridial branch, contains a large number of nuclei; and the central cell, when it is first cut off, seems to be almost entirely filled with them. They are not clearly defined on account of the affinity of the protoplasm for the stain and the slight staining capacity of their bodies. Their nucleoli alone are conspicuous (Fig. I 5, b). Later, as the central cell grows larger, they are found grouped together at its centre in a dense mass (see Fig. ${ }_{5}, c$ ).

The surrounding protoplasm is almost unstained, the nuclear bodies are now more darkly stained, and the nucleoli are not quite so conspicuous. Finally, when the central cell has attained a considerable size and is completely invested, the nuclei are scattered irregularly in it and are stained rather deeply and more uniformly. In the ascogenous hyphae the nuclei are not clearly defined, the staining of the younger branches being in particular very diffuse. Occasionally a few are found which show a structure similar to those of the 
young ascogonium, but usually they are only to be distinguished from the surrounding protoplasm by being stained rather more deeply. At the time when it is first possible to distinguish with certainty the young asci as such, four or eight nuclei are usually found in each. Eventually eight nuclei are formed in each ascus, and the spores are produced by the accumulation of protoplasm around each nucleus.

The small size of the archicarp renders it impossible to speak with more certainty of the nuclear behaviour during the earlier periods of the formation of the ascocarp. The nuclei are relatively numerous, and consequently in whatever position the young ascogonium is viewed, even in sections, some are always superposed above the others. This fact gives rise in most instances to appearances of nuclear fusions, the majority of which by very careful observation can be made out to be due simply to superposition. Some cases cannot be clearly determined. The nuclei are so small and the amount of stainable substance in them is so inconsiderable, being especially marked owing to the stained protoplasm, rendering them comparatively transparent and therefore almost indeterminable in regard to their boundaries, that a positive statement as to fusion in such cases cannot be given. Nevertheless it is highly probable that fusions occur. There is an undoubted fusion between the antheridial branch and the young ascogonium, the extent of the fusion never being much greater than will permit of the passage of nuclei. That nuclei do pass from one organ to the other at some period is certain, since they have been found in the communicating canal. The fusion always takes place prior to the formation of the wall across the archegonium, which cuts off the central cell, so that the inference is that a nucleus or nuclei passed from the antheridial branch into that region of the ascogonium before the formation of the wall.

Probably many nuclei pass, since, after the central cell is cut off, it is found to be crowded with nuclei, while the number of nuclei in the antheridial branch seems to be less than in rather younger branches. Having admitted the 


\section{I82 Barker.--The Morphology and Development of}

extreme likelihood of the course of events up to this point, supported as they are by direct observation, by every analogy it follows that the male nucleus or nuclei fuse with female nuclei in pairs in the central cell. The absence of one or two specially large or conspicuous nuclei supports the view that numerous fusions occur. The time of the occurrence of the fusions is probably during the state of aggregation of nuclei, at the centre of the central cell, when it is beginning to swell.

Confirmation of this interpretation of the nuclear behaviour is forthcoming by the analogy of Pyronema. As Harper has shown (10), a 'pore' fusion occurs in this fungus between the trichogyne and the antheridium. Numerous nuclei pass from the latter through the trichogyne into the ascogonium, which then forms a wall at the base of the trichogyne, a cell analogous to the central cell of Monascus thus being produced. Its nuclei aggregate at its centre, the male nuclei also travelling to that position, and numerous fusions in pairs then occur between the male and female nuclei. Similar multiple fusions have been shown by Stevens to occur in the oospheres of Albugo Bliti (20) and Albugo Portulacae (21), the details of the processes being essentially the same as in Pyronema. There is therefore considerable ground for believing that the nuclear behaviour in the archicarp of Monascus consists in numerous fusions in pairs of male and female nuclei in the central cell.

It has not been possible to distinguish nuclei in the act of division. It is probable, however, that some of the nuclei, which have been described above as having a structure consisting of a deeply stained nucleolus and an unstained nuclear body, are actually nuclei in course of division. If this is so, the structure which has been described above as the nucleolus consists probably of the individual chromosomes grouped closely together in one of the stages of karyokinesis, and appearing on account of the small size of the nucleus and nuclear figures as a single homogeneous structure. The somewhat irregular shape of the 'nucleolus' in some instances lends colour to this view, which is also supported by the facts 
that such nuclei are only found in young, actively growing hyphae, where dividing nuclei must certainly occur, and that the limits of the nuclei in these regions are very difficult to determine. It is noteworthy, also, that when the conspicuous 'nucleolus' disappears from a nucleus, the latter becomes more definite, and can be distinguished as a sharply marked spherical body with a reticulate network. If this view is correct, we have in Monascus another instance of active nuclear division preceding the formation of male and female gametes, so characteristic of the Oomycetes and Pyronema.

During the formation of the first few investing hyphae, nothing of peculiar interest is seen, except that the central cell increases considerably in size (see Fig. 16). During this time it stains conspicuously, and can easily be seen. As the development of the investing hyphae proceeds, the central cell still goes on increasing in size, but stains less and less conspicuously, until at last, in many cases, all sight of it is lost. Both sections and teased material at this stage represent apparently the ascocarp as possessing only numerous small hyphae (see Figs. I7 and I8). This appearance, however, is misleading. For in the teased material careful focussing reveals the fact that the hyphae apparently within the ascocarp are in reality some of the investing hyphae, which, staining deeply, appear to be within the ascocarp, though they are actually merely in view through the unseen central cell. This illusion is heightened by the fact that the latter is ovoid or spherical, so that at every plane some of the investing hyphae are sharply in focus. In the sections it is impossible to get the ascocarps cut sufficiently thin to show a section of the central cell only with a ring of investing hyphae around it. Owing to their small size at this stage some of the investing hyphae either above or below it are sure to be included in the section, and these produce the illusion.

Such appearances cease when the investing hyphae reach the swelling and flattening stage, the continued growth of the central cell also aiding the alteration. The investing hyphae above and below the central cell now become much more 


\section{I84 Barker.-The Morphology and Development of}

indistinct, and their course can hardly be traced. The only positions where they are clearly visible are at the sides of the central cell. The latter in consequence becomes clear in outline again, and its further development can be followed.

Its structure at this stage seems to be very variable.

On rare occasions it is a large, more or less spherical cell, filled with much vacuolated protoplasm and containing numerous nuclei (see Fig. 19).

Sometimes it appears as a large spherical cell-as in the preceding case, but with a prominent protuberance at some point of its surface (see Fig. 20).

More usually, however, it is a spherical body with a round cavity developed at some point within it. In this cavity is a greater or less number of hyphae, deeply stained for the most part and very conspicuous. The size and position of this cavity are very variable in ascocarps of the same size. In some the cavity is very small, is situated close to the surface of the cell, apparently coming to the surface at some point, and contains very few hyphae. Fig. 21 shows a case in which only a single hypha is present. Figs. 22, 23, 24 show instances in which only a few branching hyphae are developed. At the same time these figures show the varying positions of the cavity with reference to that of the stalk of the ascocarp, i.e. the main hypha from which the archicarp was developed.

In other instances the cavity is much larger and contains many hyphae, some small and conspicuously stained and others larger and much vacuolated. The cavity then occupies a large part of the interior of the central cell, sometimes occupying it so fully that the latter is nothing more than a thin double envelope of varying thickness, and often very difficult to distinguish from some of the investing hyphae. Figs. 25-28 represent this stage in various degrees.

The teased preparations show these examples much more clearly than the sections, since there is considerable confusion in the latter between the sections of the thinner parts of the central cell and the sections of the investing hyphae. The sections, however, show that in most cases in the cavity there 
is a large deeply-stained central hypha with many prominent nuclei, and around this, in a circle, are other smaller hyphae which seem to arise as lateral branches of the central hypha (see Figs. 23-27). In young stages there appear to be three main hyphae in the cavity, one the prominent central hypha, and the other two springing as opposite branches from this. The main central hypha thus seems to branch in a manner similar to that of the main investing hypha. Each of these hyphae branches freely later, and produces within the cavity a densely-woven mass of hyphae of various sizes. Only the small, young hyphae then stain deeply, the older ones becoming quickly filled with large vacuoles and staining but little. In later stages these swell so much and are almost unstained, so that it becomes impossible to trace their course.

As the ascocarps increase in size, the size of the cavity in the central cell becomes much greater and the mass of hyphae within it very considerable. The central cell, in a sense, seems to develop accordingly, so that the whole ascocarp is composed practically of a solid tissue. A section across such an one shows an external ring of investing hyphae, very much flattened out and consisting of very little more than cellwalls ; these are not contiguous, so that the ring is incomplete: then comes a complete ring of tissue, consisting of a section across the central cell; it has both an outer and an inner wall, and is of varying thickness. In most sections, completely enclosed by this ring, is the central cavity, filled with branching hyphae of various sizes (see Figs. 25-32).

After this stage degeneration seems to take place in the ascocarp. The internal hyphae become mixed up with a structureless substance, probably mucilaginous in nature and produced by the breaking down of some of the alder ones. Some of the branches swell up into spherical bodies, the young asci, in which eight small darkly-stained round masses appear. These are the early stages of the spores. They increase in size and eventually become developed into ripe spores, ovoid in shape, with pointed ends and thick walls. The wall of the ascocarp consists now of a complete brownish 


\section{I86 Barker.-The Morphology and Development of}

structureless thin layer of cellulose-like material, which doubtless is made up of the empty walls of both the investing hyphae and the degenerated central cell. Fig. 32 shows ascocarps at this stage, containing some asci with rudimentary spores and others with ripe spores. Further degeneration takes place within the ascocarp, the ripe spores being liberated from the asci and the remainder of the internal hyphae breaking down completely, a pseudo-sporangium being thus produced (Fig. 33).

It has been mentioned above that the central cell in some cases shows a conspicuous protuberance. This is not only seen in cases in which no cavity exists in the central cell, but also in instances where the cavity is of considerable size. In the teased preparations I have endeavoured to trace the course of such protuberances in the latter instances. As far as I can make out, the protuberance seems to be an actual outgrowth of the central cell which grows over the surface of the latter, closely applied to it, until it reaches the neighbourhood of the central cavity; then, at the point where the cavity comes nearest to the surface, it appears to penetrate into it and become continuous with the main hypha within it. I do not state positively that this is actually the case, seeing that the protuberance is not differentiated in the least from the central cell by staining, and bearing in mind that the shadow of an investing hypha may give rise to the appearance of the continuation of the protuberance above or below the central cell. But, at any rate, at certain planes the existence of such a protuberance directly from the central cell, and entirely independent of investing hyphae, is most plainly seen, and it is only about its length and course that any doubt is felt. Fig. 34 shows an example of these appearances.

In sections I have not been able to trace the course of such protuberances owing to the confusing effect of the investing hyphae.

We are now, more or less, in a position to discuss the morphological nature and mode of formation of the ascocarp from the evidence furnished by these results. 
The ascocarp evidently arises from an archicarp, as is the case with many other Ascomycetes, e.g. Sphaerotheca and Pyronema. The archicarp here consists of two organs; one a male organ, the antheridial branch, and the other, the ascogonium, or female organ. A sexual process, represented by an undoubted fusion between the two, and probably also by multiple fusion between male and female nuclei, undoubtedly occurs, the antheridial branch appearing to take the most active part in the process of fusion as indicated by the formation of the small papilla. As a result of this process, a fertilized cell, the central cell, is formed. From this, with the aid of the investing hyphae, the development of which seems to be called forth by the act of fertilization, the ascocarp is produced. The central cell swells enormously, the investing hyphae keeping pace with it at first by active growth, and later, when this ceases, by swelling and flattening. The latter effect is doubtless produced by continued growth of the central cell, which is also illustrated by the slight bulging that takes place at those portions of its surface which are uncovered by investing hyphae. The next step in the development consists in the formation of ascogenous hyphae from the central cell. It has not been possible to observe the earliest formation of these hyphae, owing among other things to difficulties in distinguishing them from investing hyphae. Nevertheless at a very young stage they have been observed as short-coiled comparatively stout hyphae situated in a kind of little nest or depression in the side of the central cell. The first appearance of this nest always coincides in point of time with the first appearance of the ascogenous hyphae as such, and it has been seen at a stage so early that it has been completely occupied by a single short-coiled hypha. It is then very small compared with the size of the central cell, and is always situated at some point of the surface of the latter, its exact position varying in different instances. It soon begins to increase in size, being all the while completely filled with closely entwined hyphae. Its growth continues, until it occupies almost the whole of the interior of the ascocarp. The ascogenous hyphae 
eventually produce small spherical eight-spored asci. The asci are very thin-walled, and soon break down, liberating the spores into the cavity of the nest, and at the same time the ascogenous hyphae also degenerate, so that the ripe ascocarp is filled with a large number of spores lying free in its interior amid a mass of mucilaginous substance produced by the degeneration of the other structures. During this time the central cell has undergone many changes. The nest of ascogenous hyphae in its growth displaces it and causes a considerable alteration in its shape. As the nest increases in size, it penetrates towards the centre of the central cell, which, in its growth, closes over it, so as to make it appear as if it were an internal development. Eventually the central cell ceases to grow, but the ascogenous hyphae continue to enlarge the size of the nest until asci are formed, thus causing the surrounding wall, which consists of the hollowed-out central cell, to become stretched and therefore thinner. The contents gradually disappear and the walls become cutinized, so that finally nothing remains of the central cell but its walls, which form a complete envelope around the asci and ascogenous hyphae. At first spherical, it thus gradually becomes changed in shape to a hollow sphere by the formation of a depression at one point, which extends by degrees to its centre, the mouth of the depression being roofed over by its growth. The depression itself is caused by the formation of ascogenous hyphae and its enlargement is due to the growth of these structures. The ripe ascocarp is thus a simple sporangium-like structure-a pseudo-sporangium. The complicated intermediate stages of its formation are due entirely to the curious behaviour of the central cell in growing around and thus enclosing the earliest formed ascogenous hyphae. It is thus in reality very simple in origin.

No other satisfactory interpretation of the structures observed during the development of the ascocarp seems possible. The ascogenous hyphae must arise from the central cell, since no trace of a possible origin from the investing hyphae has been seen. In specimens of fixed material mounted in 
balsam the central cell and its contained structures shrink away from the investing hyphae, so that it can be seen that no outgrowth from these into the central cell has given rise to the ascogenous hyphae. Moreover, it would be contrary to every analogy if they had such an origin. Another possible cause of the curious behaviour of the central cell might be that ascogenous hyphae are produced at one point of its surface, and these, during growth, press against the investing hyphae so as to force their bases into the central cell and thus displace it, so that it surrounds them. But evidence is against this view. Nowhere can the ascogenous hyphae be seen to touch the investing hyphae, and their tips are as a matter of fact directed towards the centre of the central cell, so that during growth they tend to push themselves in or their bases outwards. An actual internal development is also quite out of the question. An investigation of young ascocarps shows that the nest invariably arises at some point on the surface of the central cell.

It is highly probable that the ascogenous hyphae have their origin from a single outgrowth of the central cell. I have never seen a case in which two nests of hyphae have been formed in the same central cell, and, as far as can be ascertained by careful examination of the youngest nests, they appear to be composed of a single coiled unbranched or slightly branched hypha. Later this branches very freely.

It is difficult to see why the first ascogenous hypha should remain in close contact with the central cell and eventually become enclosed by it. One would naturally expect to find it growing out through one of the interstices of the investing hyphae, as in the case of Pyronema. Perhaps the same attraction which causes the investing hyphae to grow closely applied to the central cell holds good for it also. Undoubtedly its behaviour results in the functions of protection and nutrition being very efficiently performed for the ascogenous hyphae by the central cell and the investing hyphae. 


\section{HISTORICAL.}

Van Tieghem (24) in I884 published an account of two hitherto undescribed Fungi, which he classed with the Ascomycetes and placed among the Perisporiaceae with such little known forms as Apiosporium and Cystotheca. He considered them as constituting a new genus, which he named Monascus, having as its distinctive feature a novel form of perithecium. As its name implies, the perithecium consisted of a single ascus, invested by a covering of sterile hyphae, the small spherical body thus produced being regarded as the perithecium. The ascus itself was peculiar, in that it was for such a structure comparatively large and manyspored. Indeed, except for its cutinized wall and the absence of any columella, it resembled a sporangium much more than a typical ascus.

To describe the species somewhat in detail, one form, Monascus ruber, consisted of a much-branched regularlyseptate mycelium which produced under culture two forms of reproductive organs. In the earlier stages of the cultures conidia were formed abundantly. These were produced at the end of branches in rows of varying numbers, being formed basipetally. They were colourless and somewhat spherical bodies, in size usually IO-I2 $\mu$. Later the second type of reproduction was developed. From one of the hyphae of the mycelium a short erect branch arose, which soon ceased to grow and began to swell at its apex. Immediately beneath the swollen tip a wall was formed, cutting off a terminal hemispherical cell. The other part of the branch was divided by two or three transverse walls. Beneath the terminal cell a whorl of branches was produced. These ramified and grew around it, until it was completely covered by them, without however being absolutely in contact with them until later. Contact was established eventually by the continued swelling of the terminal cell, which in the end attained a size of $40-54 \mu$. At this period it was brick-red in colour. During its swelling the contents of the investing hyphae gradually 
disappeared, their walls finally collapsing so that their presence was only indicated by apparent reticulated thickenings of its walls. Its coloured protoplasm at length became colourless, and divided into a very large number of small oval masses, each of which became a spore. The ripe spores were oval, colourless, and refringent with homogeneous protoplasm. They measured $7-8 \mu$ and $4-5 \mu$. They were liberated by the breaking down of the wall. The perithecium sometimes remained very much smaller and contained but few spores, e.g. $16 \mu$ in diameter with 8 -10 spores, and II $\mu$ with only 4 spores. The other species, Monascus mucoroides, differed from the preceding but little except in size. The conidia were larger, being usually I $_{5}-18 \mu$ in diameter. The perithecia were also larger, having a diameter of $60-70 \mu$, and were produced at the end of a long branch or pedicel, in this respect resembling a Mucor sporangium even more than the preceding. Hence its name. The ascospores were spherical, with a mean diameter of $8 \mu$. The investing hyphae were similar; but in the early stages, while grouping themselves around the ascus as in the preceding species, they were not so closely applied to it, a considerable space being left between them and it, contact not being established until the latter had almost reached its full size. On this account Van Tieghem considered that there was no sexual relation between the ascogenous cell and any of the investing hyphae.

The next account of a member of this genus was that given by Harz in 1890 (12). Under the name Physomyces heterosporus he has described a fungus which undoubtedly is a member of Van Tieghem's genus, Monascus. It was met with in solutions of glycerine in a soap-factory in Bavaria, and attracted attention by its vivid carmine-red pigment. Its methods of reproduction were very similar to those of the preceding species. On nutrient gelatine substrata two kinds of conidia were formed, viz. torula-like conidia, borne either singly or in chains, $2.5-3.5 \mu$ in diameter, corresponding to the conidia described by Van Tieghem, and macro-conidia, borne singly, more or less egg-shaped, and larger than the 


\section{I92 Barker.-The Morphology and Development of}

preceding. The characteristic perithecia were not produced on gelatine substrata, but were soon developed in liquid media. The earliest stages of their development, which this author found, showed two or three small cells 3-4 $\mu$ in width and 2-4 times that length, situated at the apex of a branch. One of these was apparently the terminal cell of the branch, while the other one or two were placed somewhat at its side. From the central cell the 'sporangium' was eventually produced, and he hence considered it as an oogonium. Whether either of the other cells represented an antheridium he left undecided. Further observation of these structures was soon rendered impossible by the growth of investing hyphae from beneath the oogonium. By the time that the young fructification had reached the size $\mathrm{I}^{-1} 8 \mu$ the oogonium was completely covered by these hyphae. The ripe fruits were spherical, 40-53 $\mu$ in diameter, and containing numerous spherical, or slightly oval, hyaline, thick-walled, colourless, refringent spores of $4 \cdot 5-5 \cdot \mathrm{I} \mu$ diameter. Sections of unripe fructifications, fixed in alcohol, showed the central oogonium filled with dense protoplasm and fat-drops of various sizes, surrounded by a layer of investing hyphae. Later stages showed the protoplasm regularly granular; and finally the oogonium was found filled with numerous spores, in the early stages of formation polygonal, and later more or less rounded and thick-walled. The optimum temperature of growth of this species was $30-31 \mathrm{C}$. The mycelium was freely divided by septa.

Harz seems to have been ignorant of Van Tieghem's paper, a knowledge of which, in spite of the absence of figures accompanying it, would at once have shown him that he had to deal with a form of Monascus. As it was, while considering that it showed affinities with the Oomycetes, he constructed a new order, the Leptoomycetes, in which he included it with a few other little known Fungi, e.g. Helicosporangium parasiticum, Karsten, and Papulaspora sepedonioides, Preuss. To it he gave the name Physomyces heterosporus. 
In the following year Brefeld (2) published his researches on Ascoidea, Protomyces, and Thelebolus, the results of which led him to consider these forms as intermediate between the Phycomycetes and the Ascomycetes, placing them accordingly in a new group, the Hemiasci. He suggested in a footnote the possibility of Monascus belonging to it. Into this group the genus Monascus seemed to fit naturally, judging from Van Tieghem's account. It was first definitely placed there by Schröter (19), who at the same time recognized that Harz's genus Physomyces was identical with Monascus. The order Leptoomycetes was therefore re-named by him Monascaceae, and in it were included the two species, described by Van Tieghem, together with Physomyces heterosporus, renamed Monascus heterosporus, Helicosporangium, Kars. and Papulaspora, Preuss., the two latter genera being included on the authority of Harz.

No new facts with regard to the genus were brought to light until 1895, when Went published a paper on 'Le Champignon de l'Ang-quac' (27). Ang-quac is a deep purple colouring matter prepared in China, and used in Eastern Asia for cooking purposes as a pigment. It consists of coloured powdered rice, the colour being produced by a fungus growing on the rice. Went isolated this organism and found it to be a new species of Monascus, naming it $M$. purpureus because of its characteristic colour. In studying its life-history he found several new and important facts in connexion with the development of the 'sporangium,' which the previous authors had not mentioned. The first stage consisted in the formation at the end of a hypha of two branches or cells, the one straight and apparently the terminal cell of the hypha, and the other formed just below it and slightly curving around it. The latter in course of growth continued to curve more and more, until the two were bent almost at right angles to the parent hypha. Went called the curved cell the ascogenous hypha, and regarded the straight branch as the first investing hypha. The ascogenous hypha then became divided into three cells by the 


\section{I94 Barker. - The Morphology and Development of}

formation of transverse septa. The cell at the apex of the ascogenous hypha he called the terminal cell, the middle cell the sporangium, and the lower cell the pedicel. The latter proceeded to put out branches, which grew around the sporangium, completely enveloping it. At the same time, the sporangium itself was continually swelling up, reaching in some cases a diameter of $75 \mu$. The terminal cell and the first investing hypha were soon lost sight of, owing to the development of the other investing hyphae. During the enlargement of the sporangium its wall thickened and its protoplasmic contents passed through several striking changes. In the young sporangium the protoplasm contained several large vacuoles. These divided again and again until the protoplasm possessed a foam-like structure. Later it became very opaque, the vacuoles at the same time becoming exceedingly small, so that the interior of the sporangium could not be clearly seen. In the end the contents divided up into a number of spores. The exact moment of the division could not be discovered. While usually the whole of the sporangium was filled with spores, instances were occasionally met with where spores were only to be found in one portion of the sporangium, the remainder being filled with vacuolated protoplasm. When the surface of the mass of spores was carefully examined, no interstitial material was found between the spores, the latter presenting an angular appearance. The number of spores was variable, some sporangia containing only 6-IO, while others contained from 150 to 500 . When the spores were first liberated they retained their angular appearance, but soon assumed an oval shape. In size they were about $5^{-6.5 \mu} \mu$. Conidia were also produced soon after the formation of the perithecia. They resembled those described by the earlier authors. With regard to the systematic position of the fungus, Went, on Van Tieghem's authority, in the absence of the necessary literature placed it in the genus Monascus. He considered also that this genus ought to be placed among the Hemiasci, showing in particular much resemblance to Thelebolus. He also discussed 
the significance of the first investing hypha mentioned above. From its position and period of development he considered that it showed certain correspondence with the antheridial branch of certain Ascomycetes, but, in view of the facts that it had not the constant structure of such organs and that its function, as far as he had observed it, was merely that of an investing hypha, he concluded that the relationship was not clear. He observed, however, that in certain cases a second perithecium was developed from it, thus resembling the sporangial formation in Rhizopus, and therefore suggested that it might be a rudimentary organ, the vestige of another sporangium, recalling the group of sporangia that is found in Rhizopus. The value of the ascogenous hypha seemed to him clear. The sporangium corresponded to the sporangium of the Mucorini in most instances, and the pedicel to the sporangial pedicel of the latter group. In those cases, however, where the sporangium contained but 8 spores, he considered that it approached the asci of the Erysipheae, and in particular the ascus of Sphaerotheca. In such cases the resemblance to the Erysipheae was so great that it might easily be mistaken for the perithecium of one of that group.

Recently Uyeda (23) published a paper dealing with the fungus of 'Beni-koji.' This substance is used in the preparation 'Anchū,' a fermented drink of Formosa. It consists of rice-grains infected with a pigment-producing fungus. The latter he found to be a species of Monascus. His results on the development and morphology of the 'sporangium' corresponded in essentials with those of Went. The size of the 'sporangium' was usually about $28-38.5 \mu$ in diameter, and the number of spores 20-40, the latter being oval in shape and 5-6 $\mu$ in length by $4-5 \mu$ in width. A dark-red pigment was produced by the fungus. Micro- and macro-conidia and intercalary gemmae were also formed. Uyeda believed the species to be identical with Went's Monascus purpureus. 


\section{The Systematic Position of Monascus.}

Before attempting to discuss this point, in view of the results described in this paper, it seems advisable to examine the possibility that the fungus examined by me may merely bear superficial resemblances to the species of Monascus described by other authors, belonging in reality to an altogether different type.

Comparing it for the moment with $M$.purpureus, as described by Went, choosing this species on account of its more detailed description and illustration, the superficial resemblances between the two are extraordinarily pronounced, and, were not one in possession of the complete series of figures accompanying this paper, having instead in view merely such figures as Figs. II $a-d$; I3, $a$; I9, 33 ; representing intermediate and isolated stages, no hesitation would be felt in classing them together as members of the same genus or possibly even as identical Fungi. In each case the earliest stages of perithecial formation are represented by the formation of two branches at the apex of a hypha, the one straight and obviously the terminal cell of the parent hypha, and the other arising immediately beneath and curving around it. Then follows the division of the curved branch, the 'ascogonium' as it has been termed above, by transverse septa into two (or, as Went has it, into three) cells, leaving out of account for the time being the fusion which Went did not observe. The difference in the number of cells into which the ascogonium is thus divided is not of importance at this point, seeing that occasionally I found that a septum is formed across the parent hypha a little below the ascogonium, thus cutting off a cell which acts in every way similarly to the 'pedicel' cell of Went. After the division of the ascogonium by transverse septa the subsequent behaviour in both cases is for a time identical, this consisting in the swelling of the central or penultimate cell and the formation of investing hyphae from the 'pedicel' cell or the region of the parent hypha corresponding to it. After the full development of the investing 
hyphae it is still possible in a few cases (see Fig. I 9) to find a structure corresponding to that next described by Went, viz. a large sporangium-like cell invested by a wall of small hyphae. The resemblance then apparently would cease for a time were the two forms studied by series of microtome sections, owing to the formation of the internal hyphae as described above, although when viewed in the whole condition no difference would be seen. Finally, at the time of sporeformation the similarity of structure is again noticeable. The apparent angularity of the spores within the perithecium described by Went is very clearly to be seen in many cases, but I am convinced that the angularity is due to the optical effect of the arrangement of the spores under very high magnification. This can easily be verified by transverse sections in which the spores are then seen to be of the normal oval shape. The liberation of the spores is accomplished in each case by the breaking down of the perithecial walls.

After this analysis of the similarity of the two forms at different phases of the development, it will be admitted that there are strong reasons for supposing that the fungus which I have described here is closely related to $M$. purpureus. It yet remains to be shown, however, how the account of the sporangial method of spore-formation can be reconciled with the account given above of the formation of the spores in asci. That the latter method is undoubtedly the one made use of by the 'Samsu' fungus is obvious, as the accompanying figures show. Is there any possibility that it may also occur in $M$. purpureus, and that the earlier authors have overlooked it?

It has been shown earlier that the ripe perithecium bears an exceedingly strong resemblance to an invested sporangium. It has further been mentioned that the swelling of the central cell, the 'sporangium' of previous authors, can be traced for some considerable period during the development of the investing hyphae, and also that its further behaviour, when watched in the living condition, is then lost sight of owing to difficulties of observation. This is also admitted by the 


\section{I98 Barker. - The Morphology and Development of}

previous writers. It has also been stated that the subsequent stages, visible in the living condition, consist of an apparent conspicuous vacuolization of the protoplasm of the central cell, and eventually the formation of spores within it. We have seen that the apparent vacuolization is due to the formation of much entwined hyphae, produced and practically surrounded by the much enlarged and curiously-shaped central cell; and that the spores are formed in small spherical asci arising from these internal hyphae. It has also been shown that these structures can only be seen at all clearly when the material has been suitably fixed and stained at all the different periods in the development of the perithecia.

It would not be surprising, therefore, if the earlier observers had overlooked these facts. From what has been brought forward it seems probable that they did overlook them, and this is rendered fairly certain from their papers and figures.

Considering Went's paper first, it has already been noted that, when the investing hyphae had formed a more or less complete covering to the central cell or 'sporangium,' the behaviour of the latter was obscured. In a few cases it was possible to observe changes in the protoplasmic contents of the 'sporangium,' which first presented the appearance of containing large vacuoles, this stage being followed by a somewhat similar phase in which the vacuoles were smaller and the structure more foam-like, these features in the end becoming so pronounced as to render the internal structure indistinguishable, which continued until spores appeared. Although the author searched carefully he was not able to discover the exact period or method of spore-formation. His figures, which accompany the paper, include examples of all these stages. Bearing in mind the fact that he was dealing with living material, we notice that the apparent structures of the 'sporangium,' which he has described, are in essentials identical with the stages observed above under similar conditions. But we have seen that the apparent vacuolization is really due to the formation of hyphal branches from the 'sporangium,' which organ has more or less surrounded them 
owing to the exigences of the structure of the perithecium. The early large vacuoles are the first-formed hyphae, and the later small vacuoles are the numerous branches of various sizes arising from these hyphae. The confusing optical features of the mass of entwined hyphae are responsible for the opaque appearance noticeable later, while Went's failure to discern the moment and method of spore-formation is naturally due to the nature of the development of the spores in asci, they being under the surrounding conditions only clearly visible when fully formed. The apparent angularity of the spores, mentioned earlier, which gave rise to the idea that they were formed by cleavage of the protoplasm in the typical sporangial method of spore-formation-see Harper (11)-is, as already pointed out, merely an optical effect. But apart from Went's description his figures are sufficient to confirm the statements just made. His Figures 17 and 18 are practically identical with Figures $13, a, b$, of this paper.

Perhaps, however, the most convincing proof is that which may be deduced from his statement that in some of the 'sporangia' he found spores in only one region, the remainder consisting of bands of protoplasm and vacuoles. Here it is clear that he had to deal with perithecia, in which the asci were not distributed throughout, but were grouped in one portion. The nature of the protoplasmic bands and vacuoles is obvious from the preceding.

Thus we find that Went's account is based on a misinterpretation of the observed facts, and that $M$. purpureus in all probability is a true Ascomycete with a perithecial formation similar to that of the 'Samsu' fungus.

Owing to the suggested identity between $M$. purpureus and the 'Beni-koji' fungus it is necessary to examine Uyeda's results to see if any fresh evidence is forthcoming in favour of the 'sporangium' view. It has been seen that this observer's results agreed entirely with those of Went. He gives, however, two figures (Figs. 9 and 10) which may be taken as representing stages not figured by Went, his insufficient description rendering it uncertain if they merely reproduce 
the stages figured by Went in the latter's Figs. 20 and 22. Uyeda's Fig. 9 represents a section through a developing perithecium, showing a large 'sporangium' surrounded by a wall of hyphae. The 'sporangium' is undivided and filled with granular protoplasm. Apart from any question as to whether any 'internal hyphae' have been overlooked in this preparation, it may represent the stage shown in Fig. I9 of this paper, or it may represent a section through an older perithecium, in which none of the 'internal hyphae' have been included, a portion of the swollen central cell with its investment of hyphae being merely shown. Fig. 10 of this observer represents a section through a perithecium, similar in size to the preceding, but having the 'sporangium' completely divided into more or less angular areas. This, I suppose, represents the division of the protoplasm of the sporangium into spores, and may correspond to the stage which I have described above, where the ripe spores freed from the degenerated asci are lying within the perithecium and appear to be arranged in angular areas: but, judging from the figure, it probably represents the stage where the perithecium is entirely filled with dense entwined hyphae, shortly before the formation of the asci. There is then nothing in Uyeda's paper to lead one to suppose that the 'Beni-koji' fungus differs in any way from $M$. purpureus, and thus from the 'Samsu' fungus, in the nature and method of development of its perithecia.

Considering now Harz's paper on Physomyces heterosporus, seeing how closely his account of the structure and development of the 'sporangia' corresponds with the accounts given by Went and Uyeda for $M$. purpureus, it seems hardly necessary here to recount in detail the reasons for supposing that he was really dealing with a form of Monascus. It is true that he did not describe the earliest stages of perithecial formation in much detail, and that consequently no comparisons can be made as to the method of division of the ascogonial filament. But he stated that the earliest stages were represented by the formation of two or three small hyphae at the apex of a branch of the mycelium, and that 
around these other hyphae springing from their bases were developed, so as to invest them. In the latter stages he gave a figure (Fig. 7) corresponding to Uyeda's Fig. IO, to which the same arguments can be applied as have been already given for the latter. It may then fairly be concluded that Harz's Physomyces heterosporus, or, as Schröter named it, Monascus heterosporus, forms its perithecia in the same manner as $M$. purpureus.

With regard to the two species described by Van Tieghem, $M$. ruber and $M$. mucoroides, there is not a great deal to be said. We have this observer's authority for considering $M$. purpureus as a member of the same genus, and from this fact it might be deduced that he had fallen into the same error as the subsequent authors. There is not the same amount of evidence at hand, however, since no figures accompany his paper. It is of course quite possible that the Fungi described by him possess the structure which he attributed to them, but, in view of the subsequent errors in connexion with apparently similar forms, one has considerable reason for concluding that these two species are allied to the 'Samsu' fungus.

Having now examined the relationships of these various forms to one another, and having seen that there are the strongest grounds for regarding them as members of a single genus, there remains yet another point to be discussed before the characters of this genus are set forth. It concerns the behaviour and function of the structure which has been termed above the 'antheridial branch.'

It has been shown that a fusion occurs between this organ and the ascogonium, preceding the development of the latter with its subsidiary structures into the perithecium, and that this fusion is probably accompanied by a passage of nuclei from the former into the latter, and subsequent nuclear fusion in the latter: in other words, that a sexual act takes place between the antheridium and the ascogonium. Harz and Van Tieghem have not described any definite organ corresponding to the antheridial branch, doubtless having observed it and regarded it as one of the first-formed investing hyphae. 
Went and Uyeda, however, have seen and described it; and, although the former pointed out its similarity to the antheridium of certain Ascomycetes, he failed to discover the fusion between it and the ascogonium, and suggested instead that it might be a rudimentary organ, the vestige of another sporangium. Both considered that in the present case it served as nothing more than the primary investing hypha.

It seems likely that these observers have overlooked the fusion. It has been seen that the fusion is almost invisible at the time of its occurrence even under the highest powers of magnification, except in rare instances. At the time when it becomes visible, i.e. when the central cell has become much enlarged and the investing hyphae formed, they seem to have lost sight of the structure. In fact, Went stated that it was hidden by the other hyphae. These reasons, together with the significance of its constant occurrence, its time of formation, and its position, warrant us in regarding it as a true antheridial branch, and in believing that, apart from a few possible exceptional cases, in which the ascogonium may develop further parthengentially, fusion takes place between it and the latter organ. There can be no doubt in view of Went's discussion of its significance that this author would have regarded it as an antheridium, had he observed the fusion.

A minor point of interest is that which concerns the division of the ascogonium after fertilization. Both Went and Uyeda found that it became divided into three cellsthe terminal cell, the 'sporangium,' and the pedicel. From the latter the investing hyphae arose. In the 'Samsu' fungus, on the other hand, only two cells are formed-the terminal cell, which includes the place of fusion, and the central cell, corresponding to the 'sporangium.' The investing hyphae arise from the region of the present hypha immediately below the latter.

From the figures of these authors I have no reason to suppose that their account of the origin of the pedicel is not generally correct. Its size and position certainly appear to 
bear out their statement that it is cut off from the ascogonium. As stated above, I have found occasionally a cell cut off below the ascogonium which behaves in the same way as their pedicel, but it is merely a cell cut off immediately below the ascogonium, and has not constituted a portion of that organ. It is also not so conspicuous as their pedicel. In one or two instances figured by Went, however, his 'pedicel' cannot have the origin ascribed to it, and is in those cases nothing more than the cell of the parent hypha immediately below the ascogonium.

If their accounts be taken as correct for the majority of cases at least, we have in $M$. purpureus to deal with a more specialized form of perithecium than in the 'Samsu' fungus, a point which at once separates the two forms into different species; whereas if their 'pedicel ' has really an origin similar to that in the somewhat rare instances just quoted, it is highly probable that the two Fungi are members of the same species. Since they have not given figures of the successive stages in the development of a single perithecium, such as could be obtained by observations of hanging-drop cultures, it is impossible to make a more definite statement as to the identity of the forms.

We are now in a position to state in detail the characters of the genus Monascus.

The mycelium consists of much-branched, septate hyphae, which produce at certain periods two kinds, at least, of reproductive organs. The asexual organs are usually spherical or ovoid bodies, formed as a rule basipetally at the ends of branch hyphae in chains of varying lengths. They are usually colourless, but, after the formation of pigment has begun in the mycelium, they may be slightly tinged with the corresponding colour. Sexual reproduction results in the formation of ascogenous hyphae. An archicarp, consisting of an ascogonial branch and an antheridial branch, is formed usually at the end of a hypha, the former arising immediately below the latter and proceeding to grow above and around it. Both are cut off into distinct organs from the parent hypha by the 
formation of septa, the antheridial branch being usually the former apex of the parent hypha. Fusion then takes place between the two organs, followed probably by migration of nuclei from the antheridium into the ascogonium and subsequent fusion of these with the nuclei of the latter. The fertilized ascogonium then divides into a terminal cell and a central cell by the formation of a transverse septum, and possibly in some instances a third cell, the pedicel, is also cut off. The central cell begins to swell considerably, and becomes invested by hyphae, arising immediately beneath it, either from the parent branch or from the pedicel, when the latter is present. After swelling, the invested central cell produces one or more hyphae which develop vigorously and produce a mass of entangled ascogenous hyphae, which displace it to a certain extent, causing it to completely envelop them and to become closely adpressed to the enclosing investing hyphae. The latter soon become much flattened out and lose their contents, being represented in the later stages by a mere reticulum of brown cell-walls around the enlarged central cell. Asci are eventually produced from the ascogenous hyphae, and in each of them eight ascospores are usually formed. When the spores are ripe, the asci and ascogenous branches degenerate, the surrounding central cell having by this time lost its contents, remaining as a brown cuticularized enclosing wall. The spores are thus liberated into the cavity enclosed by this wall, and the ripe perithecium appears to be nothing more than a brown cuticularized sporangium-like structure. From it the spores escape by the degeneration of its walls. The number of spores is very variable. They are spherical or ovoid in shape, and possess thick walls. They are more or less red, brown, or orange in colour, and possess a very characteristic refringent appearance.

From this description it follows that the genus must be placed among the Ascomycetes. At the same time it does not very clearly fall into any well-defined group on account of the curious behaviour of the central cell and the incomplete character of its investment. At various stages of its develop- 
ment it presents interesting resemblances to several types. Unfortunately there are but few instances in which the development of the ascocarp has been followed step by step from the earliest stages, so that the range of comparison is very limited.

The archicarp is strikingly similar to the archicarp of certain species of Peziza, e.g. Peziza scutellata as described by Woronin (29): and in those instances in which the ascogonium curves spirally around the straight antheridial branch it recalls the archicarp of Penicillium - see Brefeld (3) - and many Gymnoascaceae. The young perithecia resemble the young perithecia of Sphaeria Lemaneae and Sordaria coprophila (30), and the similarity between the enlarged ascogonium of these forms and the developing central cell may also be pointed out. If the development of asci were to occur in the young perithecia of these forms, an ascocarp almost identical in structure with that of Monascus would result.

The mature perithecium with spore-containing asci is somewhat similar in structure to those of the Aspergillaceae and the multi-ascal Erysipheae.

None of the Fungi just mentioned can be classed with it throughout the complete course of the development of the perithecium, the Pezizineae and the Sphaeriales separating themselves by the structure of the mature perithecium, and the Erysipheae and Plectascineae by the method of development of the ascogonium after fertilization.

Its points of resemblance to so many widely separated groups of Ascomycetes are of particular interest when viewed in conjunction with the fact of the undoubted simplicity of the ascocarp in structure and development.

There are several features which indicate the simplicity of the genus. One of the most noticeable is the want of differentiation and of specialization of the antheridial branch and the ascogonium, shown in so many anomalous cases. Under certain conditions any living cell of any hypha of the mycelium seems to be able to take on the functions of an antheridium, and the cell immediately beneath it to produce 
the ascogonium in the normal manner, further development taking place quite normally. Often, too, a normally produced antheridium, after functioning as such, proceeds to develop ordinary vegetative hyphae or conidia; while, less often, even the ascogonium or, more accurately, the terminal cell of the ascogonium behaves similarly. There is thus shown a want of constancy in the position of development and in the specialization of the sexual organs which seems to point to their primitive nature, as compared with the more strongly defined archicarps of other Ascomycetes.

The mature ascocarp is also in reality of very simple structure. While apparently a cleistocarp, as in the Erysipheae, it is actually only of that nature because of the curious development of the central cell. The exterior investment of hyphae is very incomplete and scanty, and the whole of the hyphae within the ascocarp are ascogenous and arise from the fertilized ascogonium. The extent of the development of the ascogenous hyphae themselves is also very small, speaking comparatively, and variable, and the same holds good for the number of asci.

The sexuality of the archicarp is also little developed. The male and female organs arise not only from the same hypha, but also from the same cell of it, and therefore probably the male and female nuclei have their origin from the same nucleus or nuclei with the intervention of but few generations. The method of reproduction by conidia is also very simple. No specialized conidiophores are developed, any hypha being capable of producing conidia, these being formed simply by the formation of a wall just behind the apex of the hypha and the swelling of the terminal cell thus cut off.

The primitive nature of the ascocarp has just been mentioned. Leaving out of account the complexity introduced by the behaviour of the enlarged central cell, it is clear that the asci must be regarded as being devoid of a complete investment of sterile hyphae. The comparatively feeble development of investing hyphae would be quite insufficient 
to enclose the asci without the aid of the central cell. Viewed from this point of view, the ascocarp seems to be of the same nature as those of the Gymnoascaceae. A relationship to this group is also indicated by the shape, size, and method of development of the asci, and by the number and size of the ascospores. The archicarp is also very similar to that of Gymnoascus Reessii. In both forms the antheridium is typically a short straight hypha around which is coiled more or less the ascogonium. Fusion takes place between these organs, and the ascogonium subsequently develops further by producing a short branch, which gives rise to the ascogenous hyphae ${ }^{1}$.

While these facts point to a relationship to the Gymnoascaceae, there are certain features which are opposed to the idea of a very close connexion with this group. In the first place the investing hyphae of Monascus are only partially comparable to those of the Gymnoascaceae. In the former they arise from a definite point, i. e. immediately below the central cell; in the latter this is not so markedly the case. In the former also they grow closely applied to the ascogonium, resembling rather the earliest sterile hyphae of the ascocarps of the Aspergillaceae, Erysipheae, Sphaeriales, and Pezizineae; while in the latter the investment as a whole is of a comparatively loose character. Attention may here, however, be called to the curious development of small branched clasplike hyphae from the hyphae bearing the archicarp, at some distance below this structure (see Fig. I4), and even in some cases from neighbouring hyphae. They may serve to show a possible connexion between the investments in the cases under consideration. A second difficulty is the nature of the ascogonium. In Monascus, although filamentous when first formed, after fertilization it swells considerably, becoming more or less spherical before the production of ascogenous hyphae. In the Gymnoascaceae it remains unchanged throughout ; in some cases, e.g. in Ctenomyces serratus and Gymnoascus

\footnotetext{
${ }^{1}$ I have obtained the facts concerning Gymnoascus from Miss Dale, whose paper on the subject has not yet been published.
} 
candidus, dividing into several cells, from which the ascogenous hyphae spring, and in other cases, e. g. in Gymnoascus Reessii, growing directly out into a branch, from which the ascogenous hyphae arise. The ascogonium of Monascus therefore resembles the enlarged more or less spherical ascogonia of the Sphaeriales and Pezizineae much more than those of the Gymnoascaceae.

While these considerations tend to place it outside the Gymnoascaceae, there is nevertheless no other group of Ascomycetes in which it could be placed.

From the lower genera, such as Endomyces, Eremascus, Exoascus, and Ascocorticum, it is at once distinguished by the formation of an ascocarp.

From the Pyrenomycetes, Discomycetes and the higher Plectascineae it is distinguished by the relatively simple ascocarp.

Of the Fungi just mentioned the ripe ascocarps of the Aspergillaceae and the Erysipheae appear from a surface view to resemble strongly those of Monascus. Their internal structure is also very similar, if compared with the latter at the stage when the central cell is indistinguishable from the cutinized investing hyphae and the interior is filled with a mass of tangled hyphae and asci.

The study of the method of development in each case shows, however, that this similarity in structure is of no value as indicating a close relationship between these forms. The whole of the structures within the ascocarp of Monascus have their origin from the ascogonium, and are of the nature of ascogenous hyphae and asci. In the other forms sterile hyphae not of ascogonial origin are mingled with the ascogenous hyphae and asci.

There is a certain amount of similarity also between the archicarps of these forms. Very little is known about these structures in the Aspergillaceae, but the resemblance shown by that of Penicillium has already been mentioned. In this case, however, it has not yet been shown that fusion takes place between the sexual organs. The ascogonium moreover 
divides into several cells, from each of which ascogenous hyphae arise.

In the Erysipheae the ascogonium and antheridium arise from different hyphae. Otherwise they are very much like those of Monascus. The ascogonium, however, divides into several cells after fertilization, some or all of which produce asci.

The points of resemblance shown by the other Ascomycetes are confined to the archicarp and the earliest stages in the development of the ascocarp. The mature ascocarp of these forms, whether of the Discomycetous or Pyrenomycetous type, is a much more complicated and highly developed structure.

The archicarp of Peziza scutellata has already been referred to. Woronin (29), who has described it, found that the terminal cell of a short hyphal branch became somewhat enlarged, while from the cell immediately beneath it a small hypha was developed which grew around the former, becoming closely applied to it. He surmised that the former was the 'egg-cell' or ascogonium, and the latter the antheridium. The behaviour of the two structures was soon obscured by the development of investing hyphae, a perithecium eventually resulting. There is thus very little direct evidence to warrant the assumption that they represent sexual organs or that they retain their sexual functions : but in view, in particular, of Harper's work on Pyronema (10) and the Erysipheae (9), and also of the results of other observers, all of which tend to show that the archicarp is an organ of a sexual nature, although perhaps not necessarily always functional, to which the ascocarp owes its origin, these structures described by Woronin become invested with considerable significance and can fairly be looked upon as constituting an archicarp.

If the enlarged cell be regarded then as an ascogonium and the smaller hypha arising immediately beneath it be taken as an antheridial branch, the similarity to the corresponding structures of Monascus is very pronounced, since in both cases they are developed in close contact at the apex of a short branch. It is true that in the former case the antheri- 


\section{Io Barker.-The Morphology and Development of}

dial branch arises below the ascogonium, whereas in Monascus it forms the apex of the branch, the ascogonium being developed beneath by the formation of a new growing-point at that spot. This difference, however, is probably of no great importance, since it is merely a matter of the time of development. Where two or more structures are formed at the end of a hypha, it is the first-formed which appears to constitute the apex of the branch, and the others appear to arise below it. In reality, however, they are all terminal. It is thus with the cases in point, and in both instances eventually the ascogonium by its superior development assumes the apical position, the antheridial branch appearing to arise below it, although in Monascus the latter was really first formed.

Of the subsequent development of the ascocarp from the archicarp in Peziza scutellata we have insufficient details for further comparison. Fortunately, however, the complete series of changes in the case of Pyronema confuens, a member of the same group, is available for comparison owing to the successful and complete work of Harper (10).

This fungus differs from the former in having the antheridia and ascogonia developed on different hyphae. A slender filamentous hypha, the trichogyne, is formed as an outgrowth from the ascogonium, and fusion takes place at its tip between this and an antheridium. Nuclei then pass from the latter through the trichogyne into the ascogonium and there fuse with the nuclei of that organ. A wall is then formed cutting off the ascogonium from the trichogyne. The nuclear fusions take place during a period in which the nuclei are aggregated closely together towards the centre of the ascogonium, the outer portion of which is for the time being almost devoid of nuclei. While these processes are occurring, the neighbouring hyphae branch freely and form a close investment around the ascogonium, or rather, since these organs are usually produced in rosettes or groups, around the whole group. The ascogonium then produces numerous outgrowths, which grow out between the investing hyphae and form the ascogenous hyphae. These eventually arrange themselves in a more or 
less definite layer, intermingled with and surrounded by the sterile hyphae, and eventually produce at their tips the elongated asci, the whole fructification having by this time assumed the characteristic cup-like form.

Comparing it with Monascus, the main point of difference from the latter is the occurrence of the sexual organs on distinct hyphae, which necessitates the formation of a trichogyne. The fusion between this and the antheridium corresponds with the fusion between the tip of the ascogonium and the antheridial branch in Monascus. The passage of male nuclei then takes place in both cases, followed also by the aggregation of the mixed sexual nuclei in the ascogonium.

In both cases also the ascogonium is cut off from the antheridium by the formation of a wall; in the case of Pyronema at the base of the trichogyne, and in the case of Monascus across the ascogonium just behind the place of fusion. The apical portion, i. e. the terminal cell, of the ascogonium in Monascus may be therefore considered as equivalent to the trichogyne of Pyronema. The nature of the fusion in both cases is very similar. The fusion is in no way complete as is the case, for example, where two hyphae fuse to form a zygospore. The two fusing structures maintain their individuality, and the opening between them is no more than a small pore, just sufficiently large enough to allow of the passage of nuclei.

During the period of nuclear aggregation in Pyronema the fusions between the sexual nuclei occur. The occurrence of a similar period in Monascus makes it seem likely that the sexual nuclear fusions, which almost undoubtedly occur, take place during that time. At the end of this stage the ascogonium in each instance puts out one or more branches, the ascogenous hyphae, which ramify to a greater or less extent and eventually produce asci. The investing hyphae in Pyronema are much more strongly developed than in Monascus, but in both cases the ascogonium itself is closely invested, differing in this point from the Gymnoascaceae.

Thus, although Pyronema confluens differs from Monascus $\mathrm{P} 2$ 
so considerably in the structure of the archicarp and of the mature ascocarp, the processes leading to the formation of the latter correspond very closely in the two forms and suggest a common origin: and if the cytological behaviour of the former is characteristic of the other Pezizineae, Peziza scutellata is still more closely allied on account of its simpler archicarp.

The Sphaeriales also seem to be allied in a somewhat similar manner. Woronin (30) has described structures in Sphaeria Lemaneae and Sordaria fimiseda which must be regarded as the archicarps of these forms. The ascogonium is an enlarged spherical cell, to which is closely applied a smaller hypha, arising in the former from another and in the latter from the same branch of the mycelium, which seems to be the antheridial branch. Around these numerous coiled hyphae arising from the neighbouring portions of the mycelium grow closely applied, and a small spherical mass is thus formed. By the further development of this the characteristic perithecia are produced. The behaviour of the archicarp during this development is unknown, but it is surmised by analogy with Pyronema and other forms that it corresponds to a certain degree with these. If this be the case, the relationship suggested between the latter and Monascus would also hold good for them and other Sphaeriales.

These considerations point to the view that Monascus represents a low and comparatively simple type of Ascomycete and is not far removed from a common ancestral type, from which all the higher Ascomycetes may be supposed to have sprung. The latter are separated into distinct families by the structure of the mature ascocarp only, and there seems to be no essential difference in the nature of the reproductive organs themselves. The discovery of the archicarp or of vestiges of this structure in members of the different groups seems to indicate that the ancestral Ascomycetes possessed functional sexual organs, the ascogonium and the antheridium, the fertilization of the former by the latter resulting in the development of asci by the formation of a more or less complicated system of asco- 
genous branches from the former. The sterile hyphae, which form the investing hyphae and contribute so largely to the actual vegetative portion of the ascocarp in the higher Ascomycetes, may be regarded as a secondary development, affording the ascogenous hyphae a better opportunity of producing asci successfully: and it is the form taken by their development which determines the form of the mature ascocarp, and therefore serves to create the distinctions which characterize the various families. In Monascus we have a form that approaches very nearly this supposed ancestral type. It possesses antheridia and ascogonia which are fully functional, though simple in type and not highly differentiated, being in fact typical of a primitive form. The investing hyphae, moreover, are very subordinate, the investment being rudimentary as compared with those of the higher Ascomycetes, while the formation of subsidiary clasping hyphae (see Fig. I4) on the lower part of the hypha bearing the archicarp and on the neighbouring hyphae may be considered as a primitive form of the much more highly developed investment of the other types. It may be urged that these structures are vestiges, and that the fungus is a much reduced form, but the complete retention of sexuality together with the feebly differentiated nature of the sexual organs seems to be entirely opposed to this idea.

The gap which separates Monascus from the supposed ancestral type is small. The distinguishing features are the occurrence of investing hyphae and the envelopment of the ascogenous hyphae and asci by the enlarged central cell. An explanation of the development of these features may perhaps be arrived at by a consideration of their probable functions. The investing hyphae in the higher Ascomycetes undoubtedly serve to protect the ascogenous hyphae and also the ascogonium, while producing them. This function also seems to be exercised by them in the case of Monascus, although by the nature of the structure only the ascogonium is directly protected, and that incompletely. The cutinization of their walls in the later stages of the development of the 


\section{I4 Barker.-The Morphology and Development of}

ascocarp, and the manner of their arrangement around the central cell, certainly serve however to maintain the developing asci in a position of security within the cavity of the perithecium. Another possible function is suggested by the analogy of the investing hyphae to the auxiliary cells of the Florideae, a relationship of the Ascomycetes to this group having been considered likely by many authors. The function of the auxiliary cells seems to be that of supplying nourishment to the growing sporogenous ooblastema filaments. The investing hyphae may therefore serve to supply nutrient material to the developing central cell, and thus indirectly to the ascogenous hyphae, although no fusion takes place between them and the central cell as is the case between the ooblastema filaments and the auxiliary cells. The close application of the investing hyphae to the central cell doubtless renders fusion unnecessary.

If these are the functions of the investing hyphae generally among the higher Ascomycetes, and in a correspondingly less degree among the lower forms in which these structures are not so well developed, one would expect to find them performed in the latter instances to some extent by the ascogonium itself. The peculiar shape taken by the developing central cell in Monascus has already been mentioned above on several occasions. A little consideration shows that this shape is the one most suited to carry out the combined functions of protection and nutrition for the growing ascogenous hyphae. The protective function is undoubtedly utilized, for after it has shrunken and its walls have become cutinized the young asci are completely enclosed in the resistent envelope thus produced by it. It exercises naturally a nutritive function, since the ascogenous hyphae arise directly from it. But this is exerted in an increased degree by the method of arrangement of these hyphae in relation to it. They are so arranged that they are in close contact with it from the moment of development, and the young vigorously growing tips appear to actually press into it, the cavity erentually becoming enlarged by this means. With such 
close contact the transference of nourishment from the central cell can be carried out with much greater ease than by its passage from that organ through the whole length of the ascogenous hyphae to the growing-points. Of course in the older perithecia such close contact no longer obtains, the hyphae themselves forming a somewhat considerable mass, but it is noticeable that at comparatively late stages the central cavity seems still to owe its enlargement to the burrowing of the youngest hyphae into the central cell.

An adequate explanation is thus furnished of a unique and mysterious perithecial structure. This view explains why the first formed ascogenous hyphae do not grow out through the gaps in the reticulum of investing hyphae, but remain closely attached to and hollowing out the central cell. This most important point is apparently inexplicable except by the hypothesis just suggested; and thus fresh emphasis is laid upon the already well recognized idea that asci can only be formed by young and vigorous hyphae, which moreover can only be raised to and maintained in that condition by an abundant supply of nutriment. Perhaps some light is thrown on the nature of the required nutriment in this instance. The ascocarps are by no means always formed on aerial branches: indeed they are often completely submerged in the culture medium. When the food supply in this begins to get low, the formation of ascocarps begins. If it be the ordinary form of food that is required to keep the ascogenous hyphae in a sufficiently vigorous condition, why do they not grow out into the surrounding medium and obtain the available food, instead of trusting to the more difficult mode of supply from the central cell? It seems as if the required nutriment is a substance or substances, manufactured by the fungus from the raw food material supplied by the substratum.

The view put forward here, then, is that Monascus is a simple sexual Ascomycete, showing the relationships to the higher forms that may be expected to exist between lowly and highly organized genera of common origin, and at the 


\section{Barker.-The Morphology and Development of}

same time presenting but few features to distinguish it from the supposed ancestral types, these being, moreover, such as serve for a more successful production of ascospores.

\section{General Considerations.}

There arise in connexion with this view two questions which must be considered.

Firstly, in what relation does Monascus, as representing a type not far removed from the ancestral type, stand to the lower Ascomycetes? And secondly, does Monascus for the same reason afford any indication of the origin of the Ascomycetes from the lower Fungi or from the Algae?

These questions can perhaps best be dealt with in conjunction.

The nature of the sexual organs suggests at once a connexion with the Oomycetes, an idea already familiar through the theory of De Bary (5) as to the relationship of the various groups of Fungi. The antheridia and oogonia of this group correspond very well with the antheridial branch and ascogonium of the archicarp of Monascus. Although in most forms the sexual organs are produced on different branches, yet in some cases, e.g. most Saprolegniaceae, they are borne on the same branch, the antheridia arising immediately below the oogonia. Fertilization takes place in most cases, the antheridium becoming closely applied to the oogonium and sending into it a tube which penetrates through the periplasm and then empties the contents, in whole or in part, of the antheridium in the neighbourhood of the oosphere. After fusion of the sexual gametes, the fertilized oospore becomes invested with a thick resistant wall, to the formation of which the periplasm contributes largely. After a period of rest the oospore germinates ; in some cases, e. g. Albugo candida, producing zoospores directly, i. e. becoming converted directly into a zoosporangium; in other cases, e.g. Phytophthora omnivora, De Bary (6), forming a short promycelium, which produces a few conidia, the contents of each of which divide into eight zoospores; and in many other cases forming the ordinary 
mycelium of the fungus, on which conidia, or zoosporangia, and sexual organs are formed. An alternation of generations is thus presented by the life-history of some of these Fungi. In every instance the ordinary mycelium of the plant represents the gametophyte, while the sporophyte is represented in such forms as Phytophthora omnivora, De Bary, by the promycelium, and in such forms as Albugo candida by the oospore itself, being unrepresented in the third case quoted above. Owing to the great diversity in behaviour shown by the members of the group from the period of fertilization onwards, it is difficult to select one particular form as a type for comparison with Monascus; but there can be no doubt of the relationship of the various members of the group to one another, and therefore a general comparison will serve.

Starting with the formation of the sexual organs, the first point of difference is the formation of a special egg-cell or cells in the Oomycetes, no differentiation of such a structure being apparent in Monascus. Some or all of the nuclei of the ascogonium of the latter are, however, in all probability fertilized by the male nuclei, and these may hence be regarded as functionally similar, although apparently undifferentiated. The papilla of the antheridium of the former group, which penetrates through the periplasm of the oogonium to fertilize the oospheres, has perhaps its analogue in the small papilla produced by the antheridium of Monascus at the time of fusion between this organ and the ascogonium. The different degree of development in the two cases may be due to the fact that in the former the oospheres are specially rounded distinct bodies lying within the periplasm, and therefore not so easily reached by the male elements as the female nuclei of the latter, distributed evenly in the undifferentiated protoplasm of the ascogonium. After fusion in Monascus a special fertilized cell, the central cell, is cut out of the ascogonium, the term ' fertilized cell' being here used in the sense described by Harper (10) for the corresponding structure in Pyronema, and it is then equivalent to the oospores of the former. Instead, however, of becoming clothed with a specially 


\section{I 8 Barker. - The Morphology and Development of}

thickened wall and passing through a long period of rest, as is the case with them, it proceeds at once to swell up considerably and produce ascogenous hyphae. This process must be regarded as the germination of the fertilized 'cell' and the beginning of the sporophyte generation: and therefore corresponds with the germination of the oospore and the production of the promycelium of such a form as Phytophthora omnivora De Bary. The generation of the sporophyte is terminated in the one case by the formation of ascospores in asci, and in the other case by the formation of zoospores in sporangia. The germination of these spores in the respective instances gives rise to the gametophyte. A difference is shown in the time of germination; the zoospores, which are naked masses of protoplasm, germinating immediately after coming to rest and clothing themselves with a cell-wall, while the ascospores, which are thick-walled resistant bodies, are specially prepared to pass through a period of rest during unfavourable external conditions before germination at a suitable time. Thus the functions of the oospores are not assumed by the fertilized 'central cell,' but are passed on to the ascospores. The shifting of the period of the resting stage of the organism here indicated suffices to explain the differences of organization of the female 'cells' in the respective cases, and renders the parallel behaviour of the respective Fungi as regards the course of their life histories much closer than appears structurally. Leaving out of the question the differences which may be taken as arising naturally from the delegation of the function of hibernating to different structures in the two cases, there is a remarkable degree of resemblance in the manner and the course of the reproductive processes of these Fungi, so widely different in habit and in the structure of the mycelium. It is certainly sufficiently marked to make the idea of relationship likely.

A further point of resemblance between Monascus and the Oomycetes is the nuclear behaviour during the reproductive processes. It has been shown that in Monascus several nuclei from the antheridium probably pass into the ascogonium and 
there fuse in pairs with female nuclei as in Pyronema. Probably also there is an excess of female nuclei in the ascogonium, which remain unfertilized and eventually degenerate. The nuclei which remain in the terminal cell after the cutting off of the central cell can certainly be regarded in this light, and perhaps, too, some of the nuclei enclosed in the central cell come under this heading. Stevens has shown that in Albugo Bliti (20) and Albugo Portulacae (21) numerous male nuclei pass into the oogonium and fuse in pairs with female nuclei, while other nuclei of the oogonium remain unfertilized in the periplasm.

It is therefore necessary to examine more closely the details of these various features to determine, if possible, whether it is merely a case of parallel behaviour or whether a definite relationship is indicated.

The members of the Oomycetes which show a marked alternation of generations by the formation of a promycelium, e. g. Phytophthora omnivora, De Bary, and Pythium proliferum (6), are those which approach most nearly the simple sexual Ascomycetous type, of which Monascus is an example. In the above parallel the ascus of the latter is equivalent to the zoosporangium of the sporophyte generations of Phytophthora and Pythium. From a type similar to these forms the Ascomycetous type represented by Monascus could be derived by the suppression of the differentiated oospore stages and the transference of its hibernating function to the zoosporangia of the sporophyte, these structures becoming much more definite, owing to the acquirement of that function, and producing only a small limited number of resistant spores. Among the difficulties standing in the way of the acceptance of this hypothesis are the difference of the mycelium in the two instances, the lack of differentiation of the zoosporangia of the sporophyte from those of the gametophyte, the different methods of sporeformation in sporangia and asci, and the lack of intermediate forms.

Considering these in turn, the difference of the mycelia consists in the absence of septa, except in the reproductive 
organs, in the Oomycetes and their presence in Monascus. The cells of the latter are, however, multinucleate ; consequently the mycelium cannot be looked upon as very highly differentiated. Other Ascomycetes, e. g. Erysiphe, moreover, possess mycelia consisting chiefly of uninucleate cells. Others, e. g. Exoascus, have very much reduced mycelia. There is thus shown in the group of Ascomycetes itself a difference in the character of the mycelium at least as great as that between the two cases that are being considered.

The apparent similarity of the zoosporangia of the sporophyte and gametophyte of Phytophthora omnivora seems to make the ascus, which belongs clearly to the sporophyte, equivalent to a typically gametophytic structure. If, however, in this species the promycelium is regarded as an elementary form of sporophyte-and it has been viewed thus in the present discussion-there is a theoretical difference between the zoosporangia produced by it and those produced by the gametophyte. The delegation of the special functions of the ascus to the former would cause also a morphological distinction, so that the ascus is strictly comparable only to them. The others have their analogues in the conidia of the Ascomycetes, for both are products of the gametophyte, and among the Oomycetes conidia and zoosporangia are homologous. Harper (11) has pointed out the difference in the methods of sporeformation by cell-division in sporangia and asci. In the former the protoplasm divides directly by simple fission; in the latter a gradual aggregation of the protoplasm around each nucleus occurs. In the sporangium there is thus no epiplasm, while in the ascus it is always produced. He regards these facts as showing that there is no genetic relationship between sporangia and asci. Since the zoospores of a zoosporangium are formed by the fission method, the same objection may be raised against the homology of this type of sporangium also with the ascus. Juel (15), however, believes that the gap between the Phycomycetes and the Ascomycetes is not so wide as indicated by Harper's results, owing to the presence of periplasm in the oogonia of the Peronosporaceae, the process of the formation 
of the oospheres affording a link between the processes typical of spore-formation in sporangia and asci. It is true that it may be urged against this view that the oogonium is not homologous with the ascus or with the sporangium, and that if the two latter structures be regarded as truly homologous the gap between them remains therefore as wide as before; but it is certainly shown that in some Oomycetes there exists a method of spore-formation, although not occurring in homologous structures, which is to some extent intermediate.

Stevens (21) has shown that in Albugo Bliti, A. Portulacae and $A$. Tragopogonis the method of formation of the oosphere in the oogonium is as follows :-

The protoplasm of this organ becomes much vacuolated, clumps of denser protoplasm being distributed irregularly among the more vacuolated substance. These clumps increase in size by fusion, and eventually a single dense mass, the gonoplasm of De Bary, is formed in the centre of the oogonium surrounded by the vacuolated periplasm. The nuclei are at this stage arranged in a ring around the gonoplasm in the inner portion of the periplasm. They divide, and one or more of their daughter-nuclei enter into the gonoplasm and there fuse with the male nucleus or nuclei. It is remarkable that the sharp differentiation between the gonoplasm and the periplasm seems to be associated with the zonation stage of nuclear arrangement. Karyokinetic division of the nuclei occurs at this time simultaneously, and it seems as if this division has some connexion with the final cutting out of the oosphere. Perhaps the kinoplasm of the spindles acts in combination throughout the whole region of zonation and cuts out the compound oosphere in a manner somewhat similar to that by which the ascospores are cut out by the radiating kinoplasmic threads of the asters, which has been shown by Harper (11) to be typical of the formation of spores in asci. At any rate the processes are similar up to a certain point; for in each instance the oosphere or the ascospores are formed from a dense protoplasmic mass which gradually collects at one point in the mother-cell and is distinguished from a differentiated, 


\section{Barker. - The Morphology and Development of}

less dense and more vacuolated protoplasm, and with which eventually become associated the nucleus or nuclei which produce the nuclei of the spores. The occurrence of nuclear divisions during the period of protoplasmic differentiation is also typical of both groups. The results of Wager (25 and 26), Trow (22), Berlese (1), and Miyake (28) on various other Oomycetes also agree in most details; but the zonation stage of the nuclei is not so marked, nor is the protoplasmic aggregation so pronounced in the early stages. As Stevens remarks in connexion with Albugo candida (21), it is the absence of this preliminary aggregation which precludes the early marshalling of the nuclei into the form of a hollow sphere.

There are then many points in common between the methods of formation of oospheres in the Oomycetes and of ascospores in the Ascomycetes, and further investigation may reveal even closer resemblances in the behaviour of the kinoplasmic threads during the final mitosis during oogenesis in the former. The hypothesis that the oogonium has been evolved from a gametangium, which has been considered by Stevens (21), makes those somewhat allied methods of spore-formation of great interest in conjunction with the hypothesis of the homology of the ascus with the zoosporangium. If it be assumed that antheridia and oogonia are homologous with gametangia, it is no great step further to admit the evolution of asci from zoosporangia, seeing that among the lower Algae gametangia and zoosporangia are in many cases identical. The view of Harper may therefore not be of such importance as at first appeared, especially when it is considered that the structures which show similarity in method of spore-formation also produce spores of a similar physiological character, the presence and survival of the periplasm being thus explained.

The lack of forms intermediate in character between Oomycetes of the type of Peronospora omnivora and Ascomycetes of the type of Monascus is a point of some importance because of the width of the gap separating these forms. The lower Ascomycetes, apart from the Gymnoascaceae, are distinguished by a complete loss of sexuality or by its isogamous character, 
and the Hemiasci with one exception, viz. Dipodascus, appear to be asexual organisms. The likely forms are thus limited to Dipodascus, the heterogamous Gymnoascaceae, and perhaps the Erysipheae. The features which ought to be specially noticed are the extent of the development of the sporophyte and the nature of the asci. The sporophyte in Dipodascus is very little developed. According to Juel (15) and Lagerheim (16) the 'sporangium' is formed by the fusion of two very similar hyphae. One of these, which is regarded as the female branch, then continues to grow considerably in length, and a large number of spores are eventually formed in this outgrowth. The nuclear behaviour, described by Juel, consists in the passage of a nucleus from the male branch into the female hypha, where it fuses with one of the nuclei of the latter, both branches being multinucleate. The fertilized nucleus then divides repeatedly, and eventually, around each of these daughter-nuclei, protoplasm collects and spores are formed as in a typical ascus, the only difference being in the total number of spores produced. The sterile nuclei of the female branch seem to persist until spore formation, but take no part in it. Juel regards the 'sporangium' as equivalent to the whole system of ascogenous hyphae and asci. The 'sporangium' is accordingly to be looked upon as the sporophyte. Dipodascus therefore presents to those Oomycetes, in which the oospore itself on germination becomes a zoosporangium, exactly the same resemblances as Monascus does to the Oomycetes, which form promycelia. The resemblance is even closer, because in the other case the development of a simple form of ascocarp adds another complication. Dipodascus and Monascus seem thus to stand in much the same relation to one another as do Albugo candida and Peronospora omnivora, the distinction being rather greater, however, owing to the more highly evolved sporophyte in Monascus. The homology of the 'sporangium' of Dipodascus to the zoosporangium of the Oomycetes thus appears at first to correspond with the homology of the ascus of Monascus to the latter; but this would make the ascus and the 


\section{Barker.- The Morphology and Development of}

'sporangium' homologous, whereas it has been shown that the kind of homology between these structures is one between the whole group of asci, regarded as a unit, and the single 'sporangium.' Ought not, accordingly, the zoosporangia of the Oomycetes to be classed in a similar manner into two groups, which might be called respectively the mega- and the micro-groups? The mega-zoosporangium would, in this way, be looked upon as being formed from the whole or a portion of the thallus by the direct conversion of this into a sporangium; while the micro-zoosporangium would be formed by a differentiation of the former into sporogenous and vegetative parts, the sporogenous portions constituting the zoosporangia and being formed as specialized branches of the latter. Two kinds of zoosporangia are found among the Oomycetes, viz. the large sporangia of the Saprolegniaceae and the small conidium-like sporangia of the Pythiaceae and the Peronosporaceae. They may be taken as furnishing respectively examples of mega- and micro-sporangia, and the homologies as being between the sporangium of the former and the combined conidiophore (or sporangiophore) and conidia (or sporangia) of the latter; thus furnishing an example completely parallel with that of the 'hemi-ascus' or 'sporangium' and the ascus. The existence of such a form as Dipodascus must hence supply a strong argument in favour of the hypothesis of a relationship between the Oomycetes and the Ascomycetes. The organism itself can hardly be regarded as an intermediate form between Monascus and the nearest Oomycete, on account of the distinctions drawn above between asci, hemi-asci, mega- and micro-sporangia: it is, rather, a parallel form, but closer to its Albugo type than Monascus is to the Phytophthora type for reasons given above. It is, in addition, of importance as forming a link between the other Hemiasci, which are all asexual forms, and the sexual Ascomycetes. The relationship of these two groups follows from the above.

The Gymnoascaceae, although simple in structure, do not appear to stand in a position intermediate between Monascus 
and the Oomycetes. A comparison with the former has already been made, in which the most striking difference is the behaviour of the ascogonium, which becomes divided up into several cells, ascogenous branches being formed from each. This behaviour corresponds to that of the ascogonium of the Erysipheae, the members of which group show various degrees of complexity of the process. The simplest, or most reduced, method occurs in Sphaerotheca, in which form Harper (31) has shown that fusion takes place between the antheridium and ascogonium, followed by the fusion of a male and female nucleus and the division of the ascogonium into a few cells, one of which becomes converted directly into the single ascus. The nature of this ascus is therefore not quite the same as that of the ascus of Monascus, nor yet of the 'sporangium' of Dipodascus, but stands between the two. There is a differentiation of the ascogonium into two portions, one sterile and the other sporogenous, the two parts being separated by walls. In Dipodascus the two portions are either undifferentiated or else the sterile portion is absent. In Monascus the ascogonium itself may be considered sterile, but a portion of its branches sporogenous. There does not seem to be a form corresponding to Sphaerotheca among the Oomycetes. Perhaps the Erysipheae, the Gymnoascaceae and other Plectascineae are derived from a Dipodascus-like fungus, and are through that related to those Oomycetes, the sporophyte generation in which is represented simply by a zoosporangium. Their relation to Monascus would then be close but indirect. The Erysipheae, however, may be regarded as derived from the Monascus type, if the view that Sphaerotheca is a reduced form be accepted. The genus Erysiphe is most like the Monascus type. The ascogonium, after fertilization by a single nuclear fusion, divides into a row of several cells from the penultimate one of which the whole of the ascogenous hyphae probably arise, according to Harper (9). The ascogenous hyphae are but feebly developed and soon become in part converted into asci. The penultimate cell of the ascogonium corresponds thus to the central cell of Monascus, 
and if Went's statement as to the division of the ascogonium into three cells in Monascus purpureus is correct, the resemblance of the ascogonium in this species to that of Erysiphe is still greater than that of the 'Samsu' species. The Sphaerotheca form would thus be attained by the gradual loss of the ascogenous hyphae.

Of the other lower Ascomycetes, Eremascus, which retains a sexual process but is isogamous, is nearer to the Dipodascus type, and so probably are also the Saccharomycetes through the sexual form, Zygosaccharomyces (32). It is difficult indeed to separate either group from the Hemiasci. Endomyces shows occasionally a small hypha attached to the developing ascus. According to Brefeld (2) no sexual process takes place between the two structures, but the small hypha may be regarded as a rudimentary male branch. Thus this genus also approaches very nearly the Dipodascus type, and can only be separated from the Hemiasci by the limited number of spores in the ascus, as is the case with the other two groups just mentioned. The limited number of spores is doubtless necessitated by the small size of the ascus, the Saccharomycetes showing a variation in number corresponding with the size of the cell. The close relationship therefore indicated between these groups renders very interesting the positions of the three forms, Ascoidea rubescens, Endomyces decipiens, and Saccharomyces anomalus, all of which produce characteristic hat-shaped spores, such as are formed by no other Fungi (33).

The Exoascaceae and Ascocorticaceae seem to belong to the Dipodascus type rather than the Monascus type through such forms as Taphrina.

While Dipodascus appears to be the only sexual genus among the Hemiasci at present known, several of the asexual genera of that group merit further consideration. Of these Protomyces has been placed at different times by De Bary among the Ascomycetes (7) and later among the Ustilagineae (8); by Schröter in a special group, the Protomycetes (18), and later among the Hemiasci (19); and by Brefeld among the 
Hemiasci (2). It is now generally accepted as belonging to the latter group. It is characterized by a septate mycelium, intercalary cells of which swell up and clothe themselves with a thick wall, forming chlamydospores. They germinate by the bursting of the outer wall and the escape of the protoplasmic contents, surrounded by a wall. The contents of the cell thus extruded are multinucleate, and arrange themselves in a wall layer dividing up into spores, which eventually collect at the tip of the elongated cell thus converted into a sporangium by their division. Popta (17) has recently shown that no periplasm is produced during the division into spores, and accordingly regards the genus as being nearer to the Phycomycetes than Ascoidea, in which he finds periplasm produced, and therefore regards it as approaching the Ascomycetes. The chlamydospores of Protomyces resemble in appearance the intercalary ripened oogonia of Pythium and many Peronosporaceae. As De Bary (5) has shown, the latter are often fertilized by an antheridium formed from the cell immediately beneath or above, the fertilization taking place through the wall separating the two cells. The figures of the early stages of chlamydospore formation in Protomyces given by De Bary (7) and Brefeld (2) show that the cells on either side of the young chlamydospore are filled with dense protoplasm, so that these structures may be looked upon as representing the intercalary oogonia and antheridia of the above-mentioned Oomycetes. There is certainly no evidence of any fusion between these structures through the separating wall, but it may easily have been overlooked, as has happened in the cases of many Ascomycetes, where the fusion is only of sufficient size to allow the passage of a nucleus. The nuclear behaviour during the chlamydospore formation is entirely unknown at present, so that it is impossible to do more here than point out the resemblance to the intercalary sexual organs of the Oomycetes. But if it prove to be the case that the chlamydospore is sexually produced, it must then be regarded as an oospore, and we should have a member of the Hemiasci which retains its oospore stage. It would then have to be regarded as an 


\section{Barker.-The Morphology and Development of}

important connecting link between the Oomycetes and Ascomycetes.

Holtermann (13) has described a form, Conidiascus, which he places among the Hemiasci, in which reproductive bodies are produced as conidia like those of Peronospora, which later produce a few spores by the division of their contents, epiplasm being formed during the division. This form of reproduction is regarded as intermediate between conidia and asci, and thus serves to connect zoosporangia, which are homologous in the Peronosporaceae with conidia, and asci. The processes leading up to the formation of these structures do not seem to be thoroughly known at present, so that the comparison cannot be extended here.

Popta (17) has shown that the method of spore-formation in Ascoidea is more nearly allied to the Ascomycetous type than to that of the Phycomycetes, owing to the occurrence of periplasm. The sporangia are apparently produced asexually. Harper (11) believes that Popta's results either indicate a method of division similar to that which he has described for Pilobolus, or that the process is unique and differs from that occurring in the sporangia or asci studied up to that time.

Having reviewed briefly some of the features which seem to be of most importance in the question of relationship, there remain a few points which may be further considered. It has been seen that the antheridia and oogonia of the Oomycetes have probably been evolved from gametangia, the separate motile gametes of which have lost their individuality, and in the simplest forms such as Albugo Bliti, while several remain functional, others have lost their sexuality, or rather remain unfertilized, and constitute the periplasm, which may be supposed to have thus originated. Other forms, such as Peronospora parasitica, show a higher degree of differentiation, only one male and one female gamete remaining functional. Similarly, among the Ascomycetes, which still possess an archicarp of functional male and female organs, Monascus and Pyronema behave like Albugo Bliti, and Sphaerotheca-and Dipodascus among the Hemiasci-like Peronospora parasitica. 
In the cases of Monascus, Pyronema, and Dipodascus supernumerary gametes occur in the female organ, corresponding to the periplasm of the Peronosporaceae. In Sphaerotheca only one gamete seems to be produced in each organ; but in this case the supernumerary gametes may be considered to have disappeared during the course of evolution, since periplasm is not needed to produce a wall for an oospore, which function it assumes in the Peronosporaceae, affording perhaps a reason for its presence in that group when only one gamete of the female organ is functional.

In Pyronema and probably also Monascus, the development and behaviour of the gametes is like those in Albugo Bliti. The gametes in both organs are produced by nuclear division occurring shortly before fertilization. The female gametes aggregate into a ring or dense mass, from which the functional gametes separate.

The behaviour after fertilization is the first important point of difference. Leaving out of the question the definite oospore stage of the Oomycetes, we find that the fertilized gamete or gametes in Albugo produce directly by division numerous spores. Dipodascus and Eremascus behave similarly. In Phytophthora omnivora and most Ascomycetes, hyphae are produced from the fertilized cell which bear zoosporangia or asci. In many Oomycettes a mycelium is produced which bears fresh sexual organs. Thus in the Ascomycetes there is intercalated a definite phase in the life-history, which may be regarded as a sporophyte generation between the gametophyte generations. In the Oomycetes certain members show signs of such a phase, but it is by no means general. Seeing that Albugo Bliti still possesses the most primitive form of fertilization, and, in addition, presents an example of an intercalated sporophyte generation, the possession of two generations by the ancestral Oomycetes ought perhaps to be assumed; and those members of that group which do not possess both ought accordingly to be regarded as having lost the sporophyte phase. The question of relationship thus turns on the homology of the ascus with the zoosporangium. At present very 


\section{Barker.-The Morphology and Development of}

little is known of the cytological behaviour in the latter leading up to spore-formation. Wager (25) has shown that five to eight nuclei are present in the zoosporangia of Albugo candida, when those bodies are cut off by a wall from the sporangiophore. Each nucleus remains undivided and becomes the nucleus of a zoospore, which bodies are formed according to Büsgen (4) by the simultaneous division of the protoplasm into several distinct portions. This process is thus far removed from that occurring in typical asci. But the ascus must be regarded either as a specialized sporangium or as an entirely new structure without any homologues: and it has been seen that a method of spore-formation, which may be looked upon as approaching that found in asci, occurs in the oogonium of Albugo, and that the latter organ is probably a derivative of a gametangium. The balance of probability thus seems to rest with the view that the ascus and the zoosporangium are homologous. Moreover, Harper's results have been obtained from typical highly evolved asci and sporangia, and it is hardly to be expected that such diverse and characteristic structures would exhibit signs of a common origin, as might be obtained from more primitive forms. Ikeno's studies on Taphrina (14) show that the method of spore-formation in the asci of that genus is very different from Harper's typical method.

Apart, however, from the difficulty of the manner of celldivision there is another obstacle against the acceptance of these homologies. It arises from the behaviour of the nuclei in connexion with the formation of a typical ascus. The typical ascus is formed by the cutting off of a penultimate cell from an ascogenous hypha containing two nuclei which fuse together, leaving the young ascus uninucleate. The ascus speedily becomes multinucleate by repeated divisions of the fusion-nucleus, and each of the last formed daughter-nuclei becomes the nucleus of an ascospore. In the Oomycetes the antheridia, oogonia and zoosporangia are multinucleate from the moment of formation, and the nuclei in the latter structures become without any division the nuclei of the zoospores. 
As far as the difference between the young multinucleate sporangium and the young binucleate ascus is concerned the difficulty is perhaps not serious. In discussing earlier the nature of the ascus in various genera, it was seen that in some cases it was simply the fertilized ascogonium; in others that it was limited to a portion of that organ, the remainder being cut off into separate cells; and in others that it was a branch of the system of hyphae which was produced from the ascogonium. In other words, the result of the sexual process in the Ascomycetes varies, a greater or less distinction into fertile and sterile units being met with. The same kind of distinction is found in the Peronosporaceae in the germination of the oospore. The difference then comes simply in the extreme case to this: in the zoosporangium of the promycelium of Phytophthora omnivora (assuming that the nuclear behaviour is similar to that of Albugo) the nuclei of the spores are differentiated before enclosure of the mother-nuclei in the sporangium; and in the ascus of Pyronema, for example, the spore-nuclei are not formed until after enclosure within the ascus. That this difference is not seriously opposed to the idea of relationship is clear from the fact that the gameto-nuclei of the Oomycetes are not differentiated until after enclosure in the gametangia.

The fusion of the two nuclei of the young ascus has apparently no parallel among the Oomycetes. It may be mentioned that Trow (22) found curious 'double' nuclei in germinating oospores and conidia of Pythium ultimum, which may represent pairs of nuclei in the act of fusing, but whose significance is entirely obscure. The only other fusions which have been observed in that group are the sexual fusions in the oogonia. However, since the meaning of the fusions in asci does not seem to have been satisfactorily determined, the exact bearing of the phenomena on the question of relationship cannot be estimated at present.

In the foregoing discussion stress has been laid upon the analogy of spore-formation in oogonia and asci. The periplasm of both organs ought, therefore, to be regarded as having 


\section{Barker. - The Morphology and Development of}

originated by similar means. It has been already mentioned that the periplasm of oogonia probably represents the sexually functionless elements of a gametangium that was originally completely fertile. Assuming the origin of the ascus from the zoosporangium, the sterile nuclei have either disappeared or are represented by the two nuclei which are formed at the same time as those which fuse in the young ascus, one of which is cut off into the terminal cell of the ascogenous hypha and the other into a cell immediately beneath the penultimate ascus. The latter appears to be the most likely alternative, in which case the periplasm of the ascus represents a portion of the non-sporogenous protoplasm which has escaped being cut off into the sterile cells with the sterile nuclei.

The other reproductive organs of the Oomycetes and the Ascomycetes are in many cases clearly homologous. The conidia of the latter undoubtedly correspond to those of the Peronosporaceae, in which order many examples are presented of the transition from the zoosporangial to the conidial condition.

In the above comparisons only those Ascomycetes which possess a functional archicarp have been considered. It is, however, generally admitted by most botanists, with the exception of Dangeard, that the other members of that group are to be looked upon as sexually degenerate, and are therefore considered as having originated from sexual ancestors. Summarizing, Albugo, Pyronema, and Monascus possess a very characteristic and probably primitive method of multiple fertilization. The germination of the fertilized egg in both groups shows gradations between a direct division into spores, e. g. Albugo and Dipodascus, and a comparatively highly evolved differentiation into sterile and sporogenous structures, e. g. Phytophthora omnivora and Pyronema.

Combining these characters, the ancestral form of the Oomycetes was probably an organism possessing the method of multiple fertilization, the compound egg of which gave rise to numerous spores only by division, i. e. the species Albugo Bliti and $A$. Portulacae represent in those characters the 
primitive form. For similar reasons the ancestor of the Ascomycetes possessed probably the same characters, but no known member of the group now possesses these characters in an unaltered form, Monascus being the simplest as far as fertilization is concerned, and Dipodascus and Eremascus as far as the behaviour of the egg. The dividing line between the two groups seems to have originated by the development of the oospore stage on the one hand and the development of the ascospore stage on the other.

The probable origin of the coenogamete from gametangia, and the retention of zoosporangia in many Oomycetes, afford a link with the lower Algae.

The resemblances which have been pointed out between the Florideae and certain Ascomycetes by various authors may be explained by supposing the origin of the former from the same Algal ancestor, a somewhat parallel method of evolution having occurred from that form.

Certainly for most Ascomycetes there seems to be no reason for looking back for their origin to a simpler form than that represented by Albugo Bliti in those characters which have just been pointed out.

In conclusion, I wish to acknowledge my indebtedness to Professor Marshall Ward for much valuable help and advice, and also for permission to carry on the work in the Cambridge University Botanical Laboratory; to Miss Dale for information on the genus Gymnoascus, as yet unpublished; and to Messrs. D. T. Gwynne-Vaughan and R. H. Yapp for the material and for information concerning its economical use. 


\section{Barker. - The Morphology and Development of}

\section{BIBLIOGRAPHY.}

1. Berlese. Ueber die Befruchtung und Entwickelung der Oosphäre bei den Peronosporeen. Prings. Jahrb. der Bot., Bd. xxxi.

2. Brefeld. Untersuchungen aus dem Gesammtgebiete der Mykologie. IX. Heft : Die Hemiasci und die Ascomyceten.

3. - Botanische Untersuchungen uiber Schimmelpilze. II. Heft : Die Entwickelungsgeschichte von Penicillium.

4. Büsgen. Die Entwickelung der Phycomycetensporangien. Prings. Jahrb. der Bot., Bd. xiii.

5. De Bary. Beiträge zur Morphologie und Physiologie der Pilze. Beitr. iv.

6. — Zur Kenntniss der Peronosporeen. Bot. Zeit., I88I.

7. - Beiträge zur Morphologie und Physiologie der Pilze. Beitr. i.

8. - Vergleichende Morphologie und Biologie der Pilze. Leipzig, I884.

9. Harper. Kerntheilung und freie Zellbildung im Ascus. Prings. Jahrb. der Bot., Bd. xxx.

10. - Sexual Reproduction in Pyronema Confuens and the Morphology of the Ascocarp. Ann. Bot., vol. xiv.

11. Cell-division in Sporangia and Asci. Ann. Bot., xiii.

12. Harz. Physomyces heterosporus, n. sp. Bot. Cent., Bd. xli.

13. Holtermann. Mycologische Untersuchungen aus den Tropen. Berlin, 1900.

14. Ikeno. Studien über die Sporenbildung bei Taphrina Johansoni, Sad. Flora, I 90 I.

15. Juel. Ueber Zellinhalt, Befruchtung und Sporenbildung bei Dipodascus. Flora, I902.

16. Lagerheim, von. Dipodascus albidus, eine neue geschlechtliche Hemiascee. Prings. Jahrb. der Bot., Bd. xxiv.

17. Popta. Beitrag zur Kenntniss der Hemiasci. Flora, 1899 .

18. Schröter. Protomyces graminicola. Hedwigia, I87\%.

19. Die Hemiasci in Engler und Prantl's 'Die natürlichen Pflanzenfamilien,' I. I.

20. Stevens. The Compound Oosphere of Albugo Bliti. Bot. Gaz., 28.

21. Gametogenesis and Fertilization in Albugo. Bot. Gaz., 32.

22. Trow. Observations on the Biology and Cytology of Pythium ultimum, n. sp. Ann. Bot., 1901 .

23. Uyeda. Ueber den 'Benikoji' Pilz aus Formosa. Bot. Mag., I9or.

24. Van Tieghem. Monascus, genre nouveau de l'ordre des Ascomycètes. Bull. de la Soc. Bot. de France, 3 I.

25. WAGer. On the Structure and Reproduction of Cystopus candida. Ann. Bot., $\mathrm{x}$.

26. - On the Fertilization of Peronospora parasitica. Ann. Bot., xiv.

27. Went. Le champignon de l'Ang-Quac. Ann. des Sci. Nat., Bot., série viii. $\mathrm{I}$. 
28. Miyake. The Fertilization of Pythium de Baryanum. Ann. Bot., xv.

29. Woronin. Beiträge zur Morphologie und Physiologie der Pilze. Beitr. ii.

30. - Beiträge zur Morphologie und Physiologie der Pilze. Beitr. iii.

31. HARPer. Die Entwickelung des Peritheciums bei Sphaerotheca Castagnei. Ber. der Deut. Bot. Gesell., Bd. xiii.

32. BArker. A conjugating Yeast. Phil. Trans. Roy. Soc., Ser. B. 203.

33.

A fragrant Mycoderma Yeast, Saccharomyces anomalus. Ann . Bot. I900.

\title{
EXPLANATION OF FIGURES IN PLATES XII AND XIII.
}

\author{
Illustrating Mr. Barker's paper on Monascus.
}

Fig. I, $a-e$. Successive stages in the germination of a conidium. $\times 400$.

Fig. 2, $a-h$. Successive stages in the formation of an archicarp. $\quad \times 800$.

Fig. $3, a, b$. Two periods in the development of an archicarp, showing the branching of the antheridial branch and the formation of a conidium by it. $\times 65^{\circ}$.

Fig. 4. Intercalary formation of an archicarp. $\times 650$.

Fig. 5. An ascogonium spirally curved around an antheridium. $\times 800$.

Fig. 6. A conidium functioning as an antheridial branch. $\times 6_{5}$.

Fig. 7. Archicarp formation at the base of a chain of conidia, the lowest or which behaves as an antheridial cell. $\times 650$.

Fig. 8. Showing point of fusion between the ascogonium and the antheridial branch at some distance behind the apex of the former. $\times 800$.

Fig. 9. Showing fusion between the ascogonium and the antheridial branch, in which the papilla developed from the latter is conspicuous. $\times 3000$.

Fig. Io. Formation of papilla on the antheridial branch beyond the apex of the ascogonium, the latter having ceased to grow. $\times 65^{\circ}$.

Fig. I I, $\boldsymbol{a}-\boldsymbol{d}$. Development of investing hyphae. Successive stages. $\times 1000$.

Fig. I 2. Formation of auxiliary investing hyphae. $\times \mathrm{I}_{500}$.

Fig. I 3, a-c. Successive stages in the development of an ascocarp, showing the origin and development of the 'internal' hyphae and asci. $\times 1000$.

Fig. 14. A branch bearing an ascocarp and clasping hyphae. $\times 800$.

Fig. 15, $a-c$. Nuclear structures in archicarps. (a) Fusion between the ascogonium and antheridium doubtful : both organs crowded with nuclei, especially at the place where fusion occurs. (b) A nucleus occupying the canal between the ascogonium and antheridium. Central cell cut off and filled with nuclei. Nuclei in male branch comparatively few with sharp outlines. (c) Aggregation of nuclei in the centre of the swelling central cell. $\times 1200$.

Fig. I6. Section through young ascocarp showing comparatively large central cell surrounded completely by investing hyphae. $\times 1000$. 
Fig. 17. Section through an ascocarp of the same age with the central cell not completely in view. $\times 1000$.

Fig. I8. Section through a slightly older ascocarp, a small part only of the central cell being included. $\times$ rooo.

Fig. 19. Section through an ascocarp of the same age, showing a large undivided central cell. $\times$ I000.

Fig. 20. Similar section through a rather older ascocarp, showing a beak-like protuberance of the central cell. $\times 1000$.

Fig. 2I. Section through an ascocarp showing a large central cell with a small nest of ascogenous hyphae at one point of its surface. $\times$ 1000.

Figs. 22-24. Similar sections, showing varying position of the nest of ascogenous hyphae. $\times 1000$.

Fig. 25. Section through an ascocarp, showing the central cell as a complete ring around the ascogenous hyphae. $\times$ rooo.

Figs. 26-31. Various stages in the further development of the ascocarp, showing the increasing complexity of the internal ascogenous hyphae and variations in the extent of the development of the central cell. $\times$ 1000.

Fig. 32. Section through an ascocarp containing ripe asci. No trace of the central cell, which has degenerated. $\times$ I000.

Fig. 33. Section through a ripe ascocarp, showing spores lying free within the sporangium-like fructification. $\times 500$.

Fig. 34. Surface view of a young ascocarp, showing a conspicuous hyphal-like protuberance of the central cell. The investing hyphae are omitted with the exception of the cross sections around the central cell. $\times 1000$.

Figs. 1-14 were drawn from living material observed in hanging-drop cultures of beer-wort agar; Figs. 15-34 from fixed and stained material. Fig. I5, $a, b, c$, stained by the haematoxylin-iron-alum method, and Figs. I6-34 with safranin. 
Annals of Botany

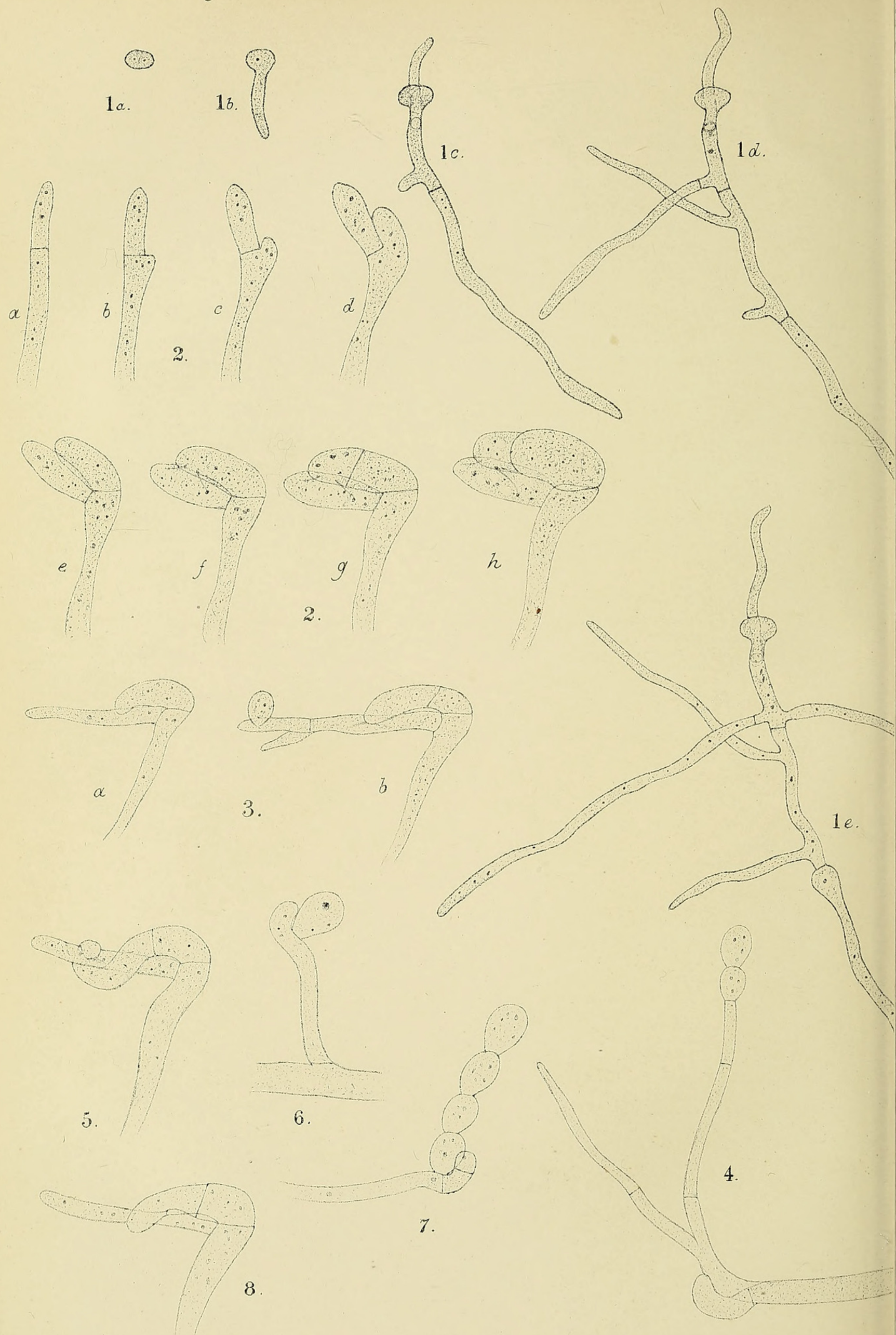

BARKER - MONASCUS. 


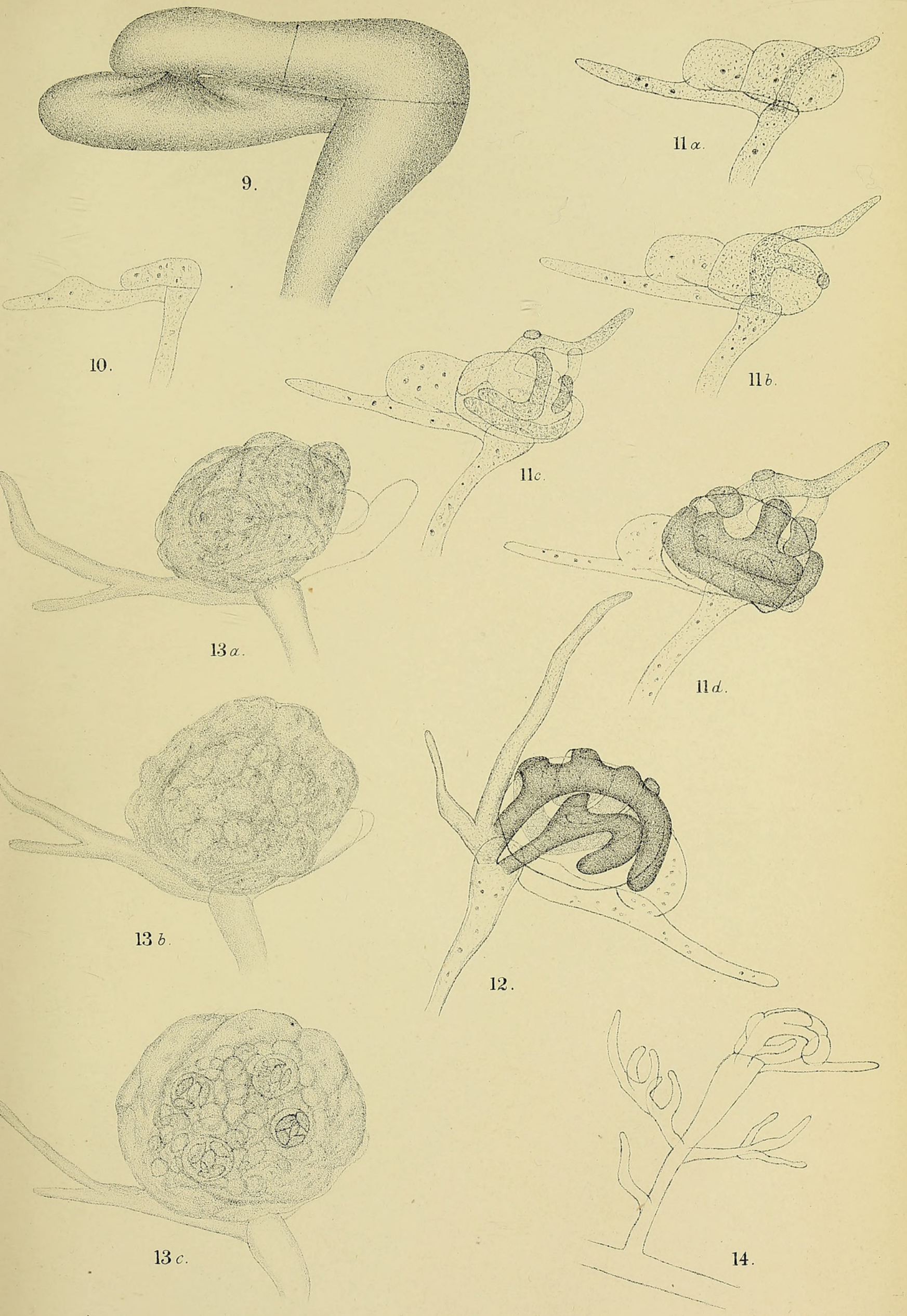

University Press, 0xford 


\section{Annals of Botany}

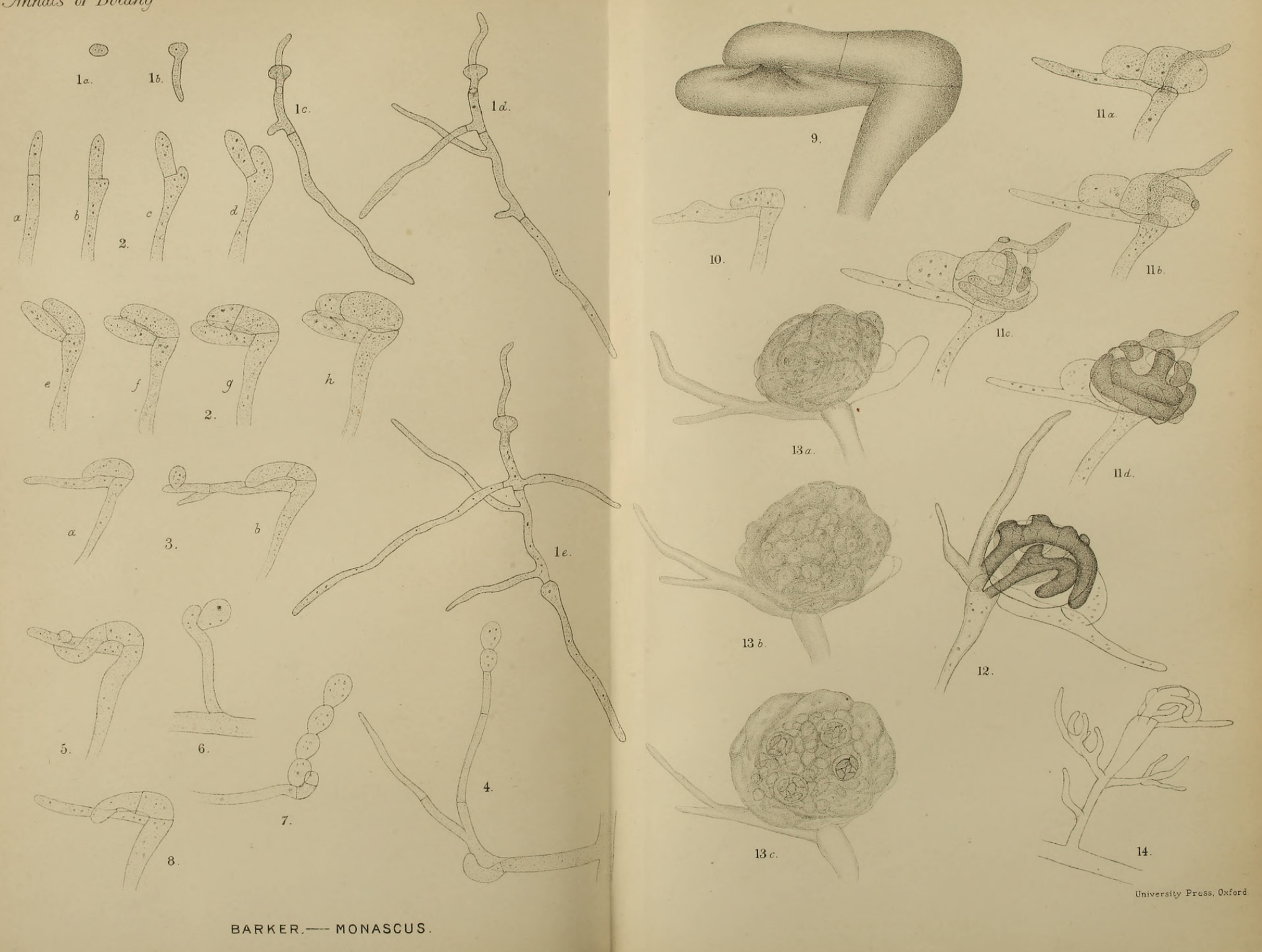



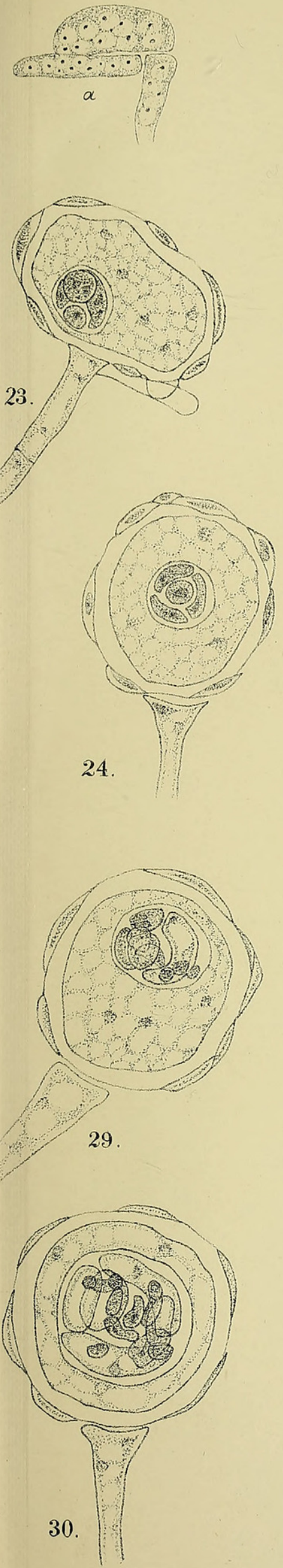

18.

16 .

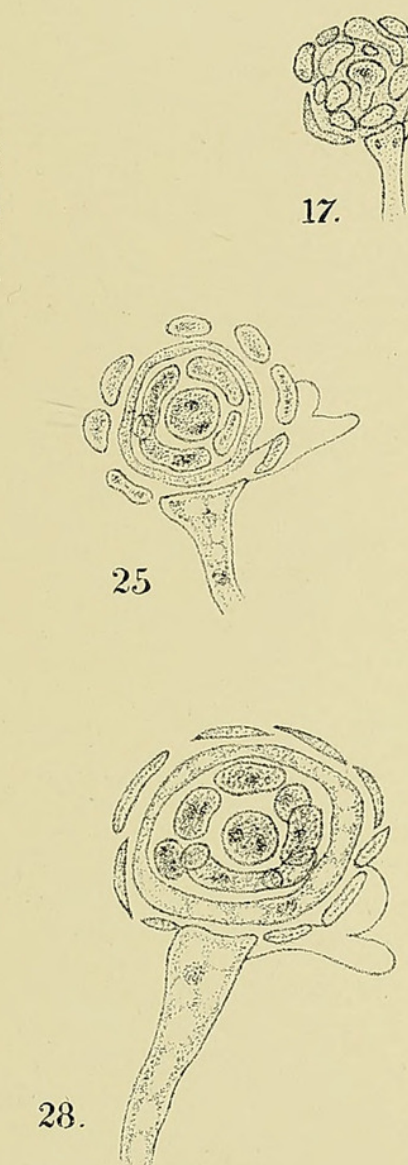

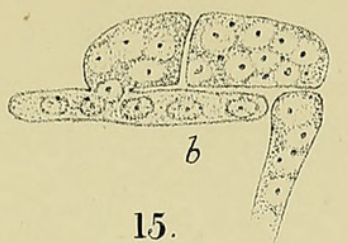
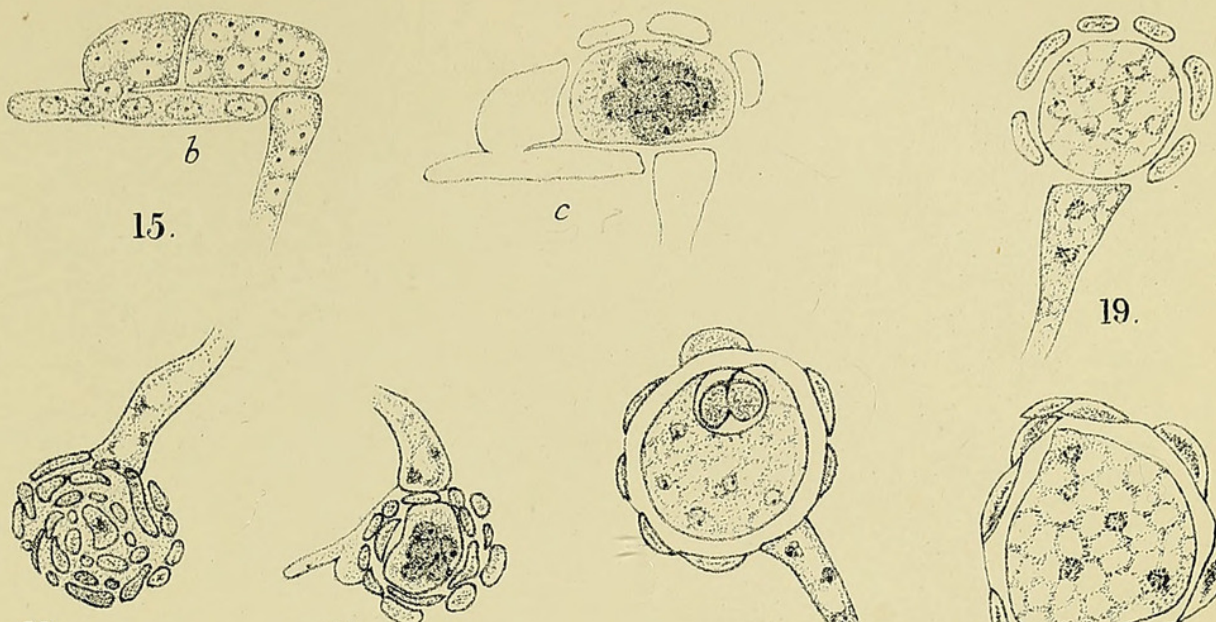

19.

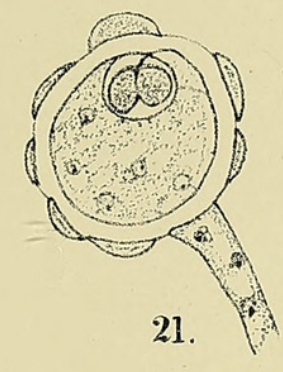

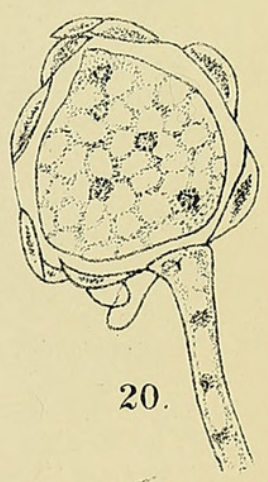
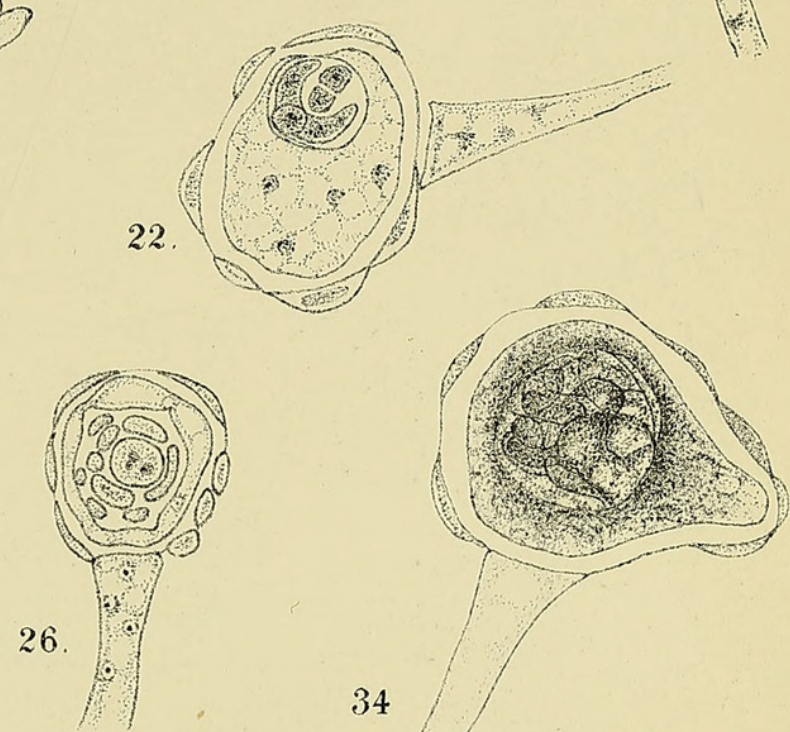

34
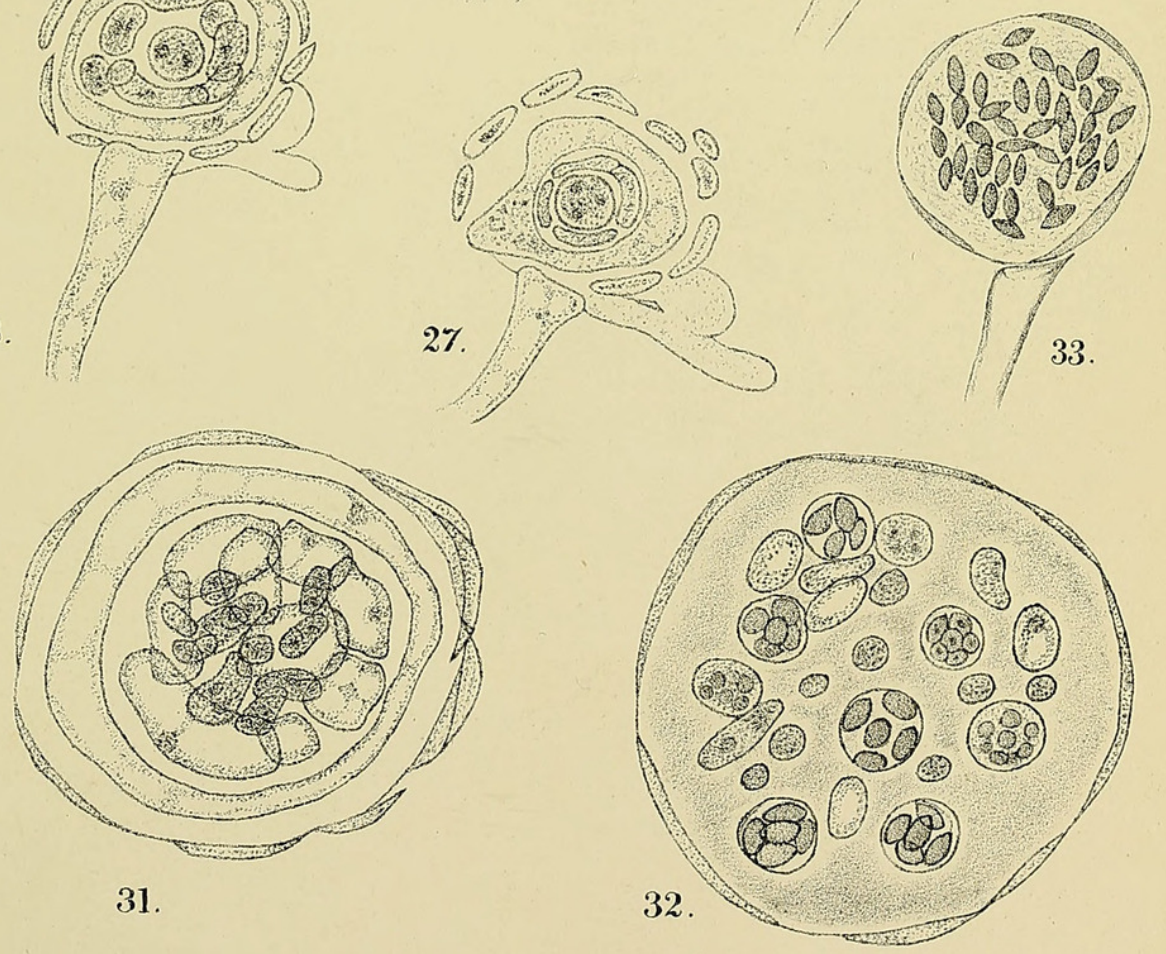


\section{$2 \mathrm{BHL}$ Biodiversity Heritage Library}

Barker, B. T. P. 1903. "The morphology and development of the ascocarp in Monascus." Annals of botany 17, 167-236.

https://doi.org/10.1093/oxfordjournals.aob.a088910.

View This Item Online: https://www.biodiversitylibrary.org/item/235015

DOI: https://doi.org/10.1093/oxfordjournals.aob.a088910

Permalink: https://www.biodiversitylibrary.org/partpdf/318709

\section{Holding Institution}

Smithsonian Libraries

\section{Sponsored by}

Biodiversity Heritage Library

\section{Copyright \& Reuse}

Copyright Status: Not in copyright. The BHL knows of no copyright restrictions on this item.

This document was created from content at the Biodiversity Heritage Library, the world's largest open access digital library for biodiversity literature and archives. Visit BHL at https://www.biodiversitylibrary.org. 